\title{
USING A DECISION-MAKING PROCESS TO EVALUATE EFFICIENCY AND OPERATING PERFORMANCE FOR LISTED SEMICONDUCTOR COMPANIES
}

\author{
Li-Chang HSU \\ Department of Finance, Ling Tung University, \\ 1 Ling Tung Road, Nantun, 40852 Taichung, Taiwan, R.O.C. \\ Received 19 February 2012; accepted 08 December 2012
}

\begin{abstract}
Today's high-tech industries face increasing competition and challenges. Thus, for hightech companies, making effective use of resources to enhance business performance and maintain the competitive advantage in the market has become increasingly important. Therefore, this study aimed to design a decision-making model for evaluating the efficiency and operating performance of Taiwan's listed semiconductor companies in 2010 to provide a basis for improving business performance. In view of this, this study combines data envelopment analysis (DEA) and improved grey relational analysis (IGRA) as efficiency tools to measure relative efficiencies; the semiconductor companies are divided into two groups, efficient and inefficient. We then integrate the multiple criteria decision making (MCDM) method (e.g. VlseKriterijumska Optimizacija I Kompromisno Resenje, VIKOR), IGRA and the entropy weight method to evaluate the operating performance of the efficient and inefficient groups, respectively. Establishing a reasonable, objective and valid evaluation model to measure semiconductor companies' operating efficiency can provide company managers, investors and policy makers with a reference for performance evaluation.
\end{abstract}

Keywords: performance evaluation, efficiency, data envelopment analysis, VIKOR, grey relational analysis, entropy weight.

JEL Classification: G11, G14, L11, L25.

\section{Introduction}

Business operators and investors are concerned about how companies view their operating strategies and whether or not they make use of their limited resources. They are also concerned with how the external environment influences the achievement of cost minimization, revenue maximization, and sustainable business performance. Today's high-tech

Corresponding author E-mail:

ltctht87@mail.ltu.edu.tw 
industries face increasing competition and challenges. Making effective use of resources to enhance production performance and maintain competitive advantage has become an increasingly important issue. Much of the previous research (Chen et al. 2006; Hung, Lu 2008; Wu et al. 2007) has paid attention to analyze input-output efficiency and the performance evaluation of the high-tech industries based on DEA. However, in addition to achieving fuller and more efficient use of resources, superior financial performance is the key success factor for companies to remain competitive in high-tech industries. Therefore, this article combines efficiency analysis, production performance and financial performance to construct an effective performance evaluation decision-making process. This approach can provide managers and investors with effective decision making process for performance evaluation.

The concept of efficiency is widely used in the empirical research of company's production performance. From the perspective of resource allocation, efficiency is defined as a minimum input or maximum output with a given set of input. Efficiency measures provide a basis for evaluating and improving company's productivity. They can also help management to understand whether or not the company is achieving effective and efficient resource allocation and use. From the internal point of view of operational efficiency, company performance can be revealed by the efficiency of resource inputs and outputs. In recent years, DEA has been widely used in the analysis of the efficiency of the industry (Cummins et al.2010; Eling, Luhnen 2010; Haugland et al. 2007; Staub et al. 2010).

In order for a business to achieve sustainable development, it must not only achieve operational efficiency, but it must also have good operational performance. For businesses, excellent operating performance is also a weapon for attracting more investors. In the hightech industry, decision makers can evaluate the operational performance of a company to understand the efficient use of resources. Meanwhile, with the results of these evaluations, decision-makers can accomplish effective utilization of company resources. Therefore, an effective measure of operating performance will help decision-makers to more effectively manage companies.

In recent years, many studies have used financial indicators to measure performance (Kozmetsky, Yue 1998). M. K. Cetin and E. I. Cetin (2010) mentioned that the financial performance evaluation of companies is a multi-criteria decision making (MCDM) problem. Therefore, MCDM methods have been used in financial performance evaluation, such as in the study by Yalcin et al. (2012), who proposed fuzzy MCDM methods for evaluating the Turkish manufacturing industry's financial performance. Wang (2009) combined grey relational analysis (GRA) with a fuzzy multi-criteria group decision-making method to evaluate the financial performance of Taiwan's container lines. Wang and Lee (2010) combined GRA with the fuzzy MCDM method to evaluate financial performance of container shipping companies. However, financial performance indicators do not adequately capture a company's operating results (Tseng et al. 2009). Thus, a combination of financial and non-financial indicators to measure operating performance is considered in this study. 
Recently, researchers have focused on combining MCDM and other methods in performance evaluation. For example, I. S. Chen and J. K. Chen (2010) used the analytical hierarchy process (AHP), GRA and the technique for order preference by similarity to ideal solution (TOPSIS) to evaluate maintenance performance. Lotfi et al. (2011) combined DEA with the TOPSIS method to rank efficient decision-making units (DMUs). Kuo and Liang (2011) combined VIKOR with GRA techniques to evaluate service quality.

Effective utilization of input resources to improve operating efficiency and to increase market competitive ability is a pursuit of each business goal. Because the level of operational efficiency within the industry, the companies competing within the industry are able to achieve different levels of operating performance. Therefore, to provide decision-makers with a clear understanding of the resource usage information enhancing their competitiveness, the proposed method can support the investors fully understand the company's business situation and make the right investment decisions. In order to effectively solve both of the problems mentioned above simultaneously, this study constructs an efficiency analysis and performance evaluation process by combining DEA and IGRA (which we call the DEA-IG model) for efficiency analysis, and then using VIKOR with GRA and the entropy weight method (which we call the VIKOR-IGE model) to evaluate the performance of listed semiconductor companies in Taiwan. An effective measure of business performance will help decision-makers to more effectively manage companies. It could also be used by investors to judge the business growth and development potential based on business performance measurement, thus assisting them in making reasonable and wise investment decisions. The concept of the proposed decision-making process is shown in Figure 1.

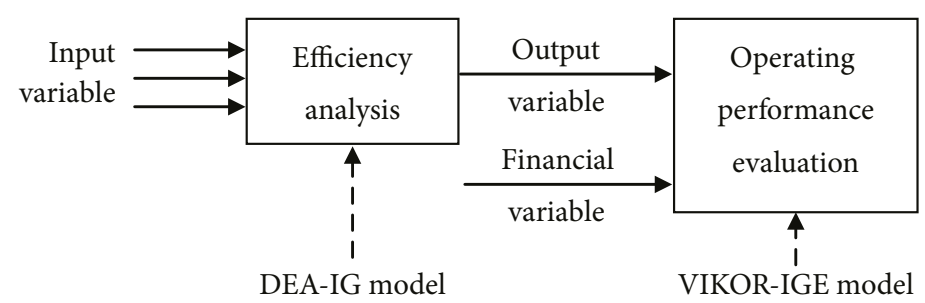

Fig. 1. A conceptual framework of the decision-making process

Many researchers are unable to clearly justify their choice for one MCDM method rather than another (Guitouni, Martel 1998). That is because each method has its own advantages and disadvantages. If we can merge two or more methods into one to overcome the shortcomings of each method, it could increase the credibility of the assessment results. Therefore, the proposed decision-making process in this study was designed in the way that combined the indicator selection method -GRA, efficiency analysis method -DEA, and MCDM method -VIKOR to improve the efficiency of decision-makers, when faced with a large number of evaluation objects. However, there are a variety of existing MCDM methods that we choose to use above decision-making process. Table 1 compares the performance 
of GRA, DEA, VIKOR and proposed process in terms of weight methods, model characteristics, researcher, method, application area, calculation time and simplicity. Table 1 also shows that each model has its own characteristics and applications. Therefore, a research methodology was applied in this study by using a combination of the characteristics of the various models, the intention is to leverage existing MCDM models to present a novel decision-making process while it applies to the efficiency measurement and performance evaluation that can contribute to the improvement of the decision-making process of both investors and management. However, in practical application, decision makers may not simultaneously have the ability to meet the above-mentioned methods, and then cannot make decisions.

Table 1. Comparison the performance of GRA, DEA, VIKOR and proposed process

\begin{tabular}{|c|c|c|c|c|c|c|}
\hline $\begin{array}{l}\text { MCDM } \\
\text { method }\end{array}$ & $\begin{array}{l}\text { Weight } \\
\text { method }\end{array}$ & $\begin{array}{l}\text { Model } \\
\text { characteristics }\end{array}$ & Researcher & Method & Application area & $\begin{array}{l}\text { Calculation } \\
\text { time/ } \\
\text { Simplicity }\end{array}$ \\
\hline \multirow[t]{4}{*}{ GRA } & \multirow[t]{4}{*}{$\begin{array}{l}\text { Equal } \\
\text { weight }\end{array}$} & \multirow[t]{4}{*}{$\begin{array}{l}\text { To deal with } \\
\text { the problem } \\
\text { of ranking and } \\
\text { selection of } \\
\text { alternatives }\end{array}$} & $\begin{array}{l}\text { Wang } \\
(2008)\end{array}$ & $\begin{array}{l}\text { GRA + } \\
\text { FMCDM }\end{array}$ & $\begin{array}{l}\text { GRA is used to determine } \\
\text { representative indicators } \\
\text { and FMCDM is used to } \\
\text { evaluate the financial } \\
\text { performance of airlines. }\end{array}$ & $\begin{array}{l}\text { Moderate/ } \\
\text { Moderately }\end{array}$ \\
\hline & & & $\begin{array}{l}\text { Kung and } \\
\text { Wen (2007) }\end{array}$ & GRA + GDM & $\begin{array}{l}\text { GRA is used to determine } \\
\text { representative indicators } \\
\text { and GDM is used to arrange } \\
\text { the total performance. }\end{array}$ & $\begin{array}{l}\text { Less/ } \\
\text { Simple }\end{array}$ \\
\hline & & & $\begin{array}{l}\text { Zolfani et al. } \\
(2012)\end{array}$ & $\begin{array}{l}\text { FAHP + } \\
\text { TOPSIS Grey, } \\
\text { SAW-G }\end{array}$ & $\begin{array}{l}\text { FAHP is used to calculate } \\
\text { weight. SAW-G and TOPSIS } \\
\text { Grey are applied for } \\
\text { evaluating alternatives. }\end{array}$ & $\begin{array}{l}\text { High/ } \\
\text { Moderately }\end{array}$ \\
\hline & & & Chen (2012) & FAHP + GRA & $\begin{array}{l}\text { FAHP is used to calculate } \\
\text { weight, and GRA is utilized } \\
\text { to rank the Taiwanese } \\
\text { automotive industry. }\end{array}$ & $\begin{array}{l}\text { Moderate/ } \\
\text { Moderately }\end{array}$ \\
\hline \multirow[t]{4}{*}{ DEA } & \multirow[t]{4}{*}{$\begin{array}{l}\text { Linear } \\
\text { program- } \\
\text { ming }\end{array}$} & \multirow{4}{*}{$\begin{array}{l}\text { Determine } \\
\text { the relative } \\
\text { efficiency } \\
\text { assessments }\end{array}$} & $\begin{array}{l}\text { Cao and } \\
\text { Yang (2011) }\end{array}$ & $\begin{array}{l}\text { Two-stage } \\
\text { DEA }\end{array}$ & $\begin{array}{l}\text { Two-stage DEA is used to } \\
\text { assess the efficiency of the } \\
40 \text { dot com firms. }\end{array}$ & $\begin{array}{l}\text { Moderate/ } \\
\text { Simple }\end{array}$ \\
\hline & & & Wu (2009) & $\begin{array}{l}\text { Three-stage } \\
\text { DEA + FPR }\end{array}$ & $\begin{array}{l}\text { Three-stage DEA/FPR is } \\
\text { developed for performance } \\
\text { evaluation. }\end{array}$ & $\begin{array}{l}\text { Moderate/ } \\
\text { Moderately }\end{array}$ \\
\hline & & & $\begin{array}{l}\text { Wang et al. } \\
(2010)\end{array}$ & $\begin{array}{l}\text { Two-stage } \\
\text { DEA + GRA }\end{array}$ & $\begin{array}{l}\text { GRA is used to determine } \\
\text { representative indicators } \\
\text { and two-stage DEA is used } \\
\text { to measure production and } \\
\text { marketing efficiencies in } \\
\text { the printed circuit board } \\
\text { industry. }\end{array}$ & $\begin{array}{l}\text { High/ } \\
\text { Moderately }\end{array}$ \\
\hline & & & $\begin{array}{l}\text { Y. S. Chen } \\
\text { and } \\
\text { B. Y. Chen } \\
(2011)\end{array}$ & DEA + MPI & $\begin{array}{l}\text { DEA is used to calculate } \\
\text { the efficiency of the wafer } \\
\text { fabrication industry and } \\
\text { MPI is used to evaluate the } \\
\text { performance change. }\end{array}$ & $\begin{array}{l}\text { Less/ } \\
\text { Simple }\end{array}$ \\
\hline
\end{tabular}


Continued Table 1

\begin{tabular}{|c|c|c|c|c|c|c|}
\hline $\begin{array}{l}\text { MCDM } \\
\text { method }\end{array}$ & $\begin{array}{l}\text { Weight } \\
\text { method }\end{array}$ & $\begin{array}{l}\text { Model } \\
\text { characteristics }\end{array}$ & Researcher & Method & Application area & $\begin{array}{l}\text { Calculation } \\
\text { time/ } \\
\text { Simplicity } \\
\end{array}$ \\
\hline \multirow[t]{5}{*}{ VIKOR } & \multirow[t]{5}{*}{$\begin{array}{l}\text { Relative } \\
\text { weight }\end{array}$} & \multirow[t]{5}{*}{$\begin{array}{l}\text { Used for } \\
\text { ranking the } \\
\text { alternatives }\end{array}$} & $\begin{array}{l}\text { Yalcin et al. } \\
(2012)\end{array}$ & $\begin{array}{l}\text { FAHP + } \\
\text { VIKOR }\end{array}$ & $\begin{array}{l}\text { FAHP is used to calculate } \\
\text { weight and VIKOR is used } \\
\text { to rank the companies } \\
\text { within each sector in the } \\
\text { Turkish manufacturing } \\
\text { industry. }\end{array}$ & $\begin{array}{l}\text { Moderate/ } \\
\text { Moderately }\end{array}$ \\
\hline & & & Sun (2011) & $\begin{array}{l}\text { FAHP + } \\
\text { VIKOR }\end{array}$ & $\begin{array}{l}\text { FAHP is used to calculate } \\
\text { weight and VIKOR is } \\
\text { used to rank the notebook } \\
\text { computer original design } \\
\text { manufacturer companies. }\end{array}$ & $\begin{array}{l}\text { Moderate/ } \\
\text { Moderately }\end{array}$ \\
\hline & & & $\begin{array}{l}\text { Fu et al. } \\
\text { (2011) }\end{array}$ & $\begin{array}{l}\text { FAHP + } \\
\text { VIKOR }\end{array}$ & $\begin{array}{l}\text { FAHP is used to calculate } \\
\text { weight and VIKOR is used } \\
\text { to rank the performance of } \\
26 \text { international hotels. }\end{array}$ & $\begin{array}{l}\text { Moderate/ } \\
\text { Moderately }\end{array}$ \\
\hline & & & $\begin{array}{l}\text { Chou et al. } \\
(2012)\end{array}$ & $\begin{array}{l}\text { Entropy + } \\
\text { VIKOR }\end{array}$ & $\begin{array}{l}\text { VIKOR and entropy weight } \\
\text { method are used to rank the } \\
\text { performance of women in } \\
\text { the science and technology. }\end{array}$ & $\begin{array}{l}\text { Less/ } \\
\text { Simple }\end{array}$ \\
\hline & & & $\begin{array}{l}\text { Nayebi et al. } \\
(2012)\end{array}$ & $\begin{array}{l}\text { AHP + } \\
\text { VIKOR + } \\
\text { BSC }\end{array}$ & $\begin{array}{l}\text { AHP is used to calculate } \\
\text { weight and VIKOR/BSC is } \\
\text { used to rank based on BSC. }\end{array}$ & $\begin{array}{l}\text { Moderate/ } \\
\text { Moderately }\end{array}$ \\
\hline $\begin{array}{l}\text { Proposed } \\
\text { process }\end{array}$ & $\begin{array}{l}\text { Entropy } \\
\text { weight }\end{array}$ & $\begin{array}{l}\text { Used for } \\
\text { ranking the } \\
\text { alternatives, } \\
\text { relative } \\
\text { efficiency } \\
\text { assessments } \\
\text { and selection } \\
\text { of alternatives }\end{array}$ & None found & $\begin{array}{l}\text { GRA + } \\
\text { DEA + } \\
\text { Entropy + } \\
\text { VIKOR }\end{array}$ & $\begin{array}{l}\text { GRA is used to determine } \\
\text { representative indicators. } \\
\text { DEA is used to assess } \\
\text { the relative efficiency. } \\
\text { VIKOR and entropy } \\
\text { weight method are used to } \\
\text { rank the performance of } \\
\text { semiconductor companies. }\end{array}$ & $\begin{array}{l}\text { High/ } \\
\text { Moderately }\end{array}$ \\
\hline
\end{tabular}

FMCDM: fuzzy MCDM, FAHP: fuzzy AHP, GDM: grey decision making, FPR: fuzzy preference relation, MPI: Malmquist productivity index, BSC: Balance Scorecard.

\section{Literature review}

\subsection{The application of GRA}

GRA is a correlation analysis method used to analyze the correlation between discrete sequence data (Deng 1988). The main advantages of GRA are that it does not need numerous data, the calculation process is simple and clear, it does not include typical probability distribution, and the conclusion does not conflict with the qualitative analysis (Bindu Madhuri, Anand Chandulal 2010). Therefore, GRA can effectively deal with discrete data. It has been widely applied to different areas such as business, management, engineering and other fields, and has resulted in good results.

GRA had been largely applied to project selection, performance evaluation and selection criteria. For example, Wang $(2008,2009)$ used GRA to select the representative indicators 
of financial ratios as evaluation criteria. Wang et al. (2010) used GRA to select the representative indicators of 32 efficiency indicators in the printed circuit board industry. Lee et al. (2012) proposed combining GRA with the entropy method to rank shipping companies. Sallehuddin and Shamsuddin (2009) used GRA to select appropriate inputs for forecasting. Lin et al. (2011) adopted GRA to determine the key success factors of the purchasing decision-making of overseas importers of Taiwanese products and Taiwanese exporters. From the above literature review, it is evident that the application of GRA for selecting representative indicators is appropriate. Therefore, in this study, GRA is used to select tools for extracting the representative factors which describe the system.

\subsection{The application of entropy method}

After Shannon and Weaver used entropy in the information theory in 1949 (Shannon, Weaver 1949), the entropy method has received rapid development and wide application. There are numerous different methods to determine the attribute weight. The entropy weight method is one such weight method. It uses the entropy value to define the weight of each indicator, so it is an objective weight method. The advantage of the entropy weight method is that it calculates the weight to avoid the influence of subjective factors based on objective data. However, it does not reflect the decision-makers' attribute preference. The entropy method is now widely used in MCDM problems as a method to measure the weights of attributes. For example, Wu and Liu (2011) proposed a VIKOR algorithm with the entropy method to deal with supplier selection problems. Shemshadi et al. (2011) proposed a fuzzy VIKOR method with the entropy method to deal with supplier selection problems. Yan et al. (2011) established an entropy-TOPSIS model to evaluate the impact of the external environment. Han and Liu (2011) proposed a TOPSIS combined with the entropy weight method to solve a hybrid multiple attribute decision-making problem. From the above literature review, it is evident that using entropy weight to deal with MCDM problems is appropriate. Therefore, this study adopts the entropy weight method to determine the attribute weights.

\subsection{The application of DEA in the high-tech industry}

As for the relationship between the inputs and outputs, the efficiency can be considered as the performance of processes that transform a set of inputs into output. Coelli et al. (1998) mentioned that the two most common ways to measure efficiency are the parametric approach and non-parametric approach. The main disadvantage of the parametric approach is the particular functional form requirement and the assumption of the distribution of the error term. In contrast, the non-parametric approach using a mathematical programming technique does not require a particular functional for the frontier, making it more flexible in its application.

The most common non-parametric approach is data envelopment analysis (DEA), which was introduced by Charnes et al. (1978). Since Charnes et al. (1978) proposed the DEA method for the evaluation of relative efficiency, it has been widely used to explore and analyze the efficiency of organizations. Avkiran (2001) pointed out that DEA is an effective and good tool for measuring efficiency. Therefore, DEA is widely used in the calculation of the relative 
efficiency of DMUs and as a performance measurement technique. It has both advantages and disadvantages. The main advantage of DEA is that it does not require the specification of a particular functional form; the weights of the decision were not influenced by subjective factors, and handle multiple inputs and outputs for calculating efficiency. However, the disadvantage of DEA is that it cannot deal with negative input or output values; thus one needs to select the input and output variables very carefully in practical applications.

In recent years, numerous scholars have used DEA for the benefit of industry, and to analyze the operating efficiency of high-tech companies. In the high-tech industry, the semiconductor industry is based on knowledge, technology and capital-intensive business. It is also a global industry. Therefore, many researchers have used the DEA method to evaluate the operating efficiency of the high-tech industry. For example, Chen et al. (2006) applied DEA to evaluate the relative efficiencies of six high-tech companies in Taiwan. Liu and Wang (2008) used DEA to measure the Malmquist productivity of semiconductor packaging and testing firms in Taiwan. Pan et al. (2008) adopted DEA models to examine the performance of the 72 integrated circuit design industry. T. Y. Chen and L. Chen (2007) used DEA to evaluate the performance of the semiconductor industry in Taiwan. Lu and Hung (2010) used DEA to evaluate the performance of the 48 semiconductor companies in Taiwan. Lu (2011) adopted DEA to evaluate the production efficiency of Taiwan's integrated circuit (IC) subsectors. Hung and Liu (2010) used DEA to analyze the influence of perfluorocompounds (PFCs) on the operating performance of the semiconductor industry.

DEA is based on the concept of relative efficiency. DEA can be used to measure the relative operational efficiency of decision making units and it can effectively process multiple inputs and multiple outputs models. Moreover, researches have confirmed that DEA appropriates evaluating the efficiency of the semiconductor industry. Therefore, this study combined DEA and IGRA (DEA-IG model) to evaluate the operating efficiency of the semiconductor industry in Taiwan.

\subsection{The application of the VIKOR method for performance evaluation}

MCDM is an appropriate tool for analyzing decision problems when facing multiple conflicting criteria. It can help the decision maker to make more accurate decisions, and it is often used in the evaluation and selection of the object. There are many types of MCDM methods which have been widely used in various fields, such as business and financial management, transportation and logistics, manufacturing and assembly, managerial and strategic planning, project management and evaluation, and so on (Toloie-Eshlaghy, Homayonfar 2011). This study focused on the application of MCDM to evaluate and rank the performance of semiconductor companies. However, selecting a feasible and effective method for evaluation of performance is not an easy task.

Numerous MCDM methods have been used in the past. Different MCDM techniques suit different kinds of decision analysis situations. Zavadskas and Turskis (2011) gave a good review and classification of the MCDM approach in economics. They classified the MCDM methods into eleven categories, i.e. the AHP (Hadi-Vencheh, Mohamadghasemi 2011), the utility additive method (UTA) (Athawale et al. 2011), complex proportional assessment (COPRAS) 
(Podvezko 2011), TOPSIS (Han, Liu 2011), VIKOR (Ginevičius et al. 2010), the additive ratio assessment method (ARAS) (Bakshi, Sarkar 2011), simple average weight (SAW) (Podvezko 2011), elimination and choice translating reality (ELECTRE) (Kaya, Kahraman 2011), the preference ranking organization method for enrichment evaluation (PROMETHEE) (Ishizaka, Nemery 2011), multi-objective optimization by ratio analysis (MOORA) (Baležentis, Baležentis 2011) and the game theory (Stein 2010).

Among the MCDM methods, TOPSIS and VIKOR to deal with the competitive nature of all criteria ranking on the basis of the concept of compromise (Opricovic, Tzeng 2004). Some previous studies have compared these two models. For example, Opricovic and Tzeng (2004) compared TOPSIS and VIKOR, showing their similarity and some differences. Chu et al. (2007) compared three MCDM methods, SAW, TOPSIS and VIKOR, showing that both the TOPSIS and VIKOR methods are suitable for evaluating similar problems, but VIKOR is easy for choice appropriate strategies. Liu and Wang (2011) also mentioned that VIKOR is generally suitable for decision making problems.

Therefore, the VIKOR method has been used by researchers to solve decision making problems. For example, Lu and Tang (2011) used the VIKOR method for evaluating auto parts suppliers. Kuo and Liang (2011) combined VIKOR and interval-valued fuzzy sets to evaluate the performance of intercity bus companies. Tsai et al. (2010) used the VIKOR method to rank Taiwanese national park websites. F. L. Chen and Y. C. Chen (2010) used the VIKOR method to rank life insurance companies in Taiwan. Shaverdi et al. (2011) used the TOPSIS, VIKOR, and ELECTRE methods to rank banking performance. From the above literature review, it is evident that VIKOR is commonly used in evaluation. Thus, this study aimed to combine VIKOR with IGRA and the entropy weight method (VIKOR-IGE model) to evaluate and rank the performance of semiconductor companies.

\section{Methodology}

\subsection{IGRA}

GRA was used to analyze the relationship between two series. It can deal effectively with multi-variable input, less data and data distribution unknown to overcome the disadvantages of traditional statistical methods. Today, GRA is widely and commonly used as a method for selecting representative indicators, such as Ho (2006), Hsu (2014), Huang and Wan (2011), Kung and Wen (2007), Lee et al. (2012) and Li (2011). Therefore, this study applies IGRA as an indicator selection method for (1) selecting input and output variables to use in the DEA model, (2) selecting representative indicators of financial ratios for evaluating performance.

Before conducting GRA, in order to achieve comparability between sequences, the data series must be normalized. There are three different types of data normalization, including the larger the better, the smaller the better, and the nominal the better. Details are shown as follows:

(1) the larger the better

$$
\gamma_{i j}=\frac{x_{i j}-\min _{i} x_{i j}}{\max _{i} x_{i j}-\min _{i} x_{i j}},
$$


(2) the smaller the better

$$
\gamma_{i j}=\frac{\max _{i} x_{i j}-x_{i j}}{\max _{i} x_{i j}-\min _{i} x_{i j}}
$$

(3) the more nominal the better

$$
\gamma_{i j}=\frac{\left|x_{i j}-x_{o b j}\right|}{\max _{i} x_{i j}-x_{o b j}}
$$

where $\max x_{i j} \geq x_{i j} \geq \min x_{i j}, x_{o b j}$ is the desired value of the $j$ th quality characteristic.

GRA includes localized and globalized grey relational grades. If the conductor chooses an arbitrary sequence as a reference sequence and other sequences are compared to the sequence, it is called localized GRA. If each sequence can be the reference sequence, then, it is called globalized GRA. This study used the globalized GRA method. However, traditional GRA is not a perfect method. The disadvantage of traditional GRA is that the value of grey relational grade between the alternative and the ideal alternative is too close. It results that it does not clearly identify the correlation between the two sequences. This study proposed the globalized IGRA method modify traditional GRA based on the improved grey relational grade. The steps of the globalized IGRA method are described as follows:

Step 1. Calculate the grey relational coefficient: Wong and Lai (2000) proposed a grey relational coefficient to improve the Deng's grey relational coefficient calculation, as follows:

$$
\gamma\left(x_{i}(k), x_{j}(k)\right)=\left\{\frac{\Delta_{\max }-\Delta_{i j}(k)}{\Delta_{\max }-\Delta_{\min }}\right\}^{\zeta}
$$

where $k=1,2, \cdots, n, i=1,2, \cdots, m, j \in i, \Delta_{i j}(k)=\left|x_{i}(k)-x_{j}(k)\right|$ is the absolute value of difference between $x_{i}(k)$ and $x_{j}(k) \cdot \Delta_{\max }=\max _{i} \max _{j} \max _{k}\left|x_{i}(k)-x_{j}(k)\right|$ and $\Delta_{\min }=\min _{i} \min _{j} \min _{k}\left|x_{i}(k)-x_{j}(k)\right|$ are the maximum and the minimum value of $\Delta_{i j}(k)$, respectively, and $\varsigma$ is the distinguishing coefficient, $\varsigma \in[0,1]$. In general, it is set to 0.5 (Wen 2004).

In this study, we consider the distance between the evaluation object and the optimal solution; we use the adjustment coefficient $\eta$ to adjust the proportion of the sort and to construct the grey relational coefficient as follows:

$$
\gamma^{\prime}\left(x_{i}(k), x_{j}(k)\right)=\eta\left\{\frac{\Delta_{\max }-\Delta_{i j}(k)}{\Delta_{\max }-\Delta_{\min }}\right\}^{\zeta}+(1-\eta)\left[1-\frac{\Delta_{i j}(k)}{\Delta_{\max }}\right],
$$

where $k=1,2, \cdots, n, i=1,2, \cdots, m, j \in i, 1-\frac{\Delta_{i j}(k)}{\Delta_{\max }}$ is the distance term, adjustment coefficient $\eta$ was set as 0.5 , which is the same value used in distinguishing coefficient. 
Step 2. Calculate the grey relational grade: The grey relational grade is obtained from the average of the grey relational coefficient, as follows:

$$
\Gamma_{i j}=\Gamma\left(x_{i}, x_{j}\right)=\frac{1}{n} \sum_{k=1}^{n} \gamma^{\prime}\left(x_{i}(k), x_{j}(k)\right),
$$

where $\Gamma_{i j}$ indicates the magnitude of correlation measured between the reference sequences $\left(x_{i}\right)$ and the comparison sequence $\left(x_{j}\right)$.

Step 3. Construct the grey relational coefficient matrix: A grey relational coefficient matrix is composed of each grey relational grade from Eq. (6), that is:

$$
M_{m \times m}=\left[\begin{array}{cccc}
\Gamma_{11} & \Gamma_{12} & \cdots & \Gamma_{1 m} \\
\Gamma_{21} & \Gamma_{22} & \cdots & \Gamma_{2 m} \\
\vdots & \vdots & \ddots & \vdots \\
\Gamma_{m 1} & \Gamma_{m 2} & \cdots & \Gamma_{m m}
\end{array}\right]_{m \times m} .
$$

Step 4. According to the equation $\operatorname{det}(M-\lambda I)=0$, find the maximum eigenvalue $\lambda_{\max }$.

Step 5. Choose the eigenvector corresponding to the largest value $\lambda_{\max }$ and rank the grey relational ordinal according to the result.

\subsection{Entropy weight method}

Shannon (1948) proposed the concept of entropy, which is a measure of information and uncertainty. In recent years, entropy has been applied to measure attribute weights (Han, Liu 2011; Lee et al. 2012; Shemshadi et al. 2011; Wu, Liu 2011; Yan et al. 2011). As mentioned in Section 1.2, the entropy weight method has the advantage to solve the weight calculation problem. Therefore, this study adopts the entropy weight method to calculate the weight value. The steps are shown as follows:

Step 1. Normalize the original evaluation matrix: There are many methods for data normalization. Chiang and Hsieh (2009) proposed Eqs (1)-(3) for data normalization, obtaining the following matrix:

$$
F=\left[\begin{array}{cccc}
\gamma_{11} & \gamma_{12} & \cdots & \gamma_{1 n} \\
\gamma_{21} & \gamma_{22} & \cdots & \gamma_{2 n} \\
\vdots & \vdots & \ddots & \vdots \\
\gamma_{m 1} & \gamma_{m 2} & \cdots & \gamma_{m n}
\end{array}\right]_{m \times n}
$$

where $\gamma_{i j}$ is the data of the $i$ th evaluating object on the $j$ th indicator, and $\gamma_{i j} \in[0,1]$.

Step 2. Calculate the entropy value of evaluation indicator $j$ : According to Wen (2004), the entropy value of the $j$ th is defined as follows:

$$
e_{j}=\frac{1}{0.6487 m} \sum_{i=1}^{m} W e\left(\frac{\gamma_{i j}}{D_{j}}\right)
$$

where: $j=1,2, \ldots, n, W_{e}=x e^{(1-x)}+(1-x) e^{x}-1, D_{j}=\sum_{i=1}^{m} \gamma_{i j}$. 
Step 3. Determine the weight of the evaluation criteria $w_{j}$ : According to Wen (2004), the weight of the evaluation component is as follows:

where: $E=\sum_{j=1}^{n} e_{j}$.

$$
w_{j}=\frac{\frac{1}{n-E}\left[1-e_{j}\right]}{\sum_{j=1}^{n} \frac{1}{n-E}\left[1-e_{j}\right]}, j=1,2, \ldots, n,
$$

\subsection{DEA-IG model}

DEA is a mathematical method for measuring the relative efficiencies of DMUs based on multiple inputs and outputs. It is used to distinguish between efficient and inefficient DMUs. Farrell (1957) developed a method using the production frontier approach to measure technical efficiency and price efficiency, in order to establish a mathematical programming model to measure efficiency. Later, Charnes et al. (1978) measured the efficiency value under multiple inputs and outputs with the assumption of constant return to scale. Their approach is called data envelopment analysis (CRS or the CCR model). Subsequently, Banker et al. (1984) proposed a model to relax the assumption of CRS by introducing the variable returns to scale (VRS) (known as the BCC model), making the DEA model more generous. According to Cooper et al. (2000), there are two types of efficiency measure in DEA, radial and non-radial measure. The above-mentioned CCR and BCC models are based on the radial measure. As for the non-radial measure, Tone (2001) proposed a slack-based measure (SBM), which based on the slack variables, is used to overcome the weakness in the CCR and BCC models. It shows that the SBM model has higher discrimination power than that of radial measure models. Therefore, this study used the SBM, CCR and BCC models to analyze the efficiency of semiconductor companies.

The mathematical expressions of the DEA models are as follows:

(1) CCR model

The CCR model assumes that the frontier is constant returns to scale, as proposed by Charnes et al. (1978). Suppose there are $n$ DMUs $(j=1, \cdots, n)$, with $m$ input $X_{i}(i=1, \cdots, m)$ to generate $s$ outputs $Y_{r}(r=1, \cdots, s)$. Then, the efficiency values of $\mathrm{DMU}_{0}\left(h_{i}\right)$ are as follows:

$$
\begin{aligned}
\operatorname{Max} \quad h_{i}= & \frac{\sum_{r=1}^{s} u_{r} Y_{r j}}{\sum_{i=1}^{m} v_{i} X_{i j}} ; \\
\text { s.t. } & \frac{\sum_{r=1}^{s} u_{r} Y_{r j}}{\sum_{i=1}^{m} v_{i} X_{i j}} \leq 1,
\end{aligned}
$$

where: $u_{r}, v_{i} \geq \varepsilon>0, j=1, \cdots, n, i=1, \cdots, m, r=1, \cdots, s . X_{i j}, Y_{r j}$ are $i$ th input and $r$ th output of $j$ th DMU; $u_{r}$ and $v_{i}$ are the weights of the input and output; $\varepsilon$ is a very small positive number, usually set to $10^{-6}$, where there is a small non-Archimedean number (Charnes, Cooper 1984). 
(2) BCC model

Banker et al. (1984) improved the CCR model and proposed the BCC model by assuming that VRS can measure both the pure technical efficiency (PTE) and scale efficiency (SE) as a way to explain the cause for the formation of weak efficiency in the CCR model. Therefore, the BCC model is a measure of pure technical efficiency. The CCR model measures the technical efficiency (TE), and the difference is the scale efficiency, where SE=TE/PTE. Two commonly used DEA orientation models are the input-oriented and output-oriented models of BCC. The input-oriented model measures how many fewer input resources can maintain the same level of outputs. The output-oriented model uses the same input level to yield more output.

The semiconductor industry involves build-to-order (BTO) operation, which requires meeting market demands for changes in input resources. Therefore, in this study, we chose the input oriented model. The analytical model is as follows:

$$
\begin{gathered}
\operatorname{Max} \quad g_{j}=\sum_{i=1}^{s} u_{r} Y_{r j}-u_{0} ; \\
\text { s.t. } \quad \sum_{i=1}^{m} v_{i} X_{i j}=1 ; \\
\sum_{i=1}^{s} u_{r} Y_{r j}-\sum_{i=1}^{m} v_{i} X_{i j} \leq 0,
\end{gathered}
$$

where: $u_{r}, v_{i} \geq \varepsilon>0 ; j=1, \cdots, n ; i=1, \cdots, m ; r=1, \cdots, s$.

(3) SBM model

The SBM was first proposed by Tone (2001), which was non-radial and took into account the input and output slacks. It has the following three features: unit invariant, monotonicity, and efficiency index value only by the efficiency reference set. Suppose there are $n$ DUMs, with $m$ input factors and $s$ output factors. Let $x_{i j}$ and $y_{i j}$ denote the $i$ th input and output of DMU $j$. The input-oriented SBM model evaluates the technical efficiency $\tau^{*}$ of $\operatorname{DMU}\left(x_{o}, y_{o}\right)$ is as follows (Cooper et al. 2006; Tone, Tsutsui 2010):

$$
\begin{aligned}
& \underset{\lambda, s^{-}}{\operatorname{Min}} \tau^{*}=1-\frac{1}{m} \sum_{i=1}^{m} \frac{s_{i}^{-}}{x_{i o}} ; \\
& \text { s.t. } x_{i o}=\sum_{j=1}^{n} x_{i j} \lambda_{j}+s_{i}^{-} \text {; } \\
& y_{i o}<\sum_{j=1}^{n} y_{i j} \lambda_{j} \\
& \lambda_{j} \geq 0, s_{i}^{-} \geq 0, i=1,2, \cdots, m,
\end{aligned}
$$

where: $\tau^{*}$ is the SBM of technical efficiency value; $\lambda_{j}$ is the weight of DMU $j ; s^{-}$is the non-radial input slacks. It can be obviously identified that $0<\tau^{*} \leq 1$. A DMU is efficient when $\tau^{*}=1$ and it is inefficient if $\tau^{*}<1$. 
Therefore, we propose the DEA-IG model to evaluate the relative efficiency of the semiconductor companies. First, we use globalized IGRA to select representative indicators for input and output variables. Then, we apply a DEA model using the CCR, BCC and SBM methods to assess the relative efficiency of these companies. The steps as follows:

Step 1. Use globalized IGRA to select representative indicators for input and output variables: First, for data normalization, since the smaller the input the better, we adopt Eq. (2) to normalize input data. However, the larger the output is the better, so we adopt Eq. (1) to normalize output data. Then, following the steps given in Section 2.1 (Steps 1-5), we can obtain the input and output of the grey relational ordinal, respectively. Finally, select the larger grey relational grade of the input and output variables as representative indicators for DEA.

Step 2. Using the selected input and output variables to solve the problem with the CCR model (Eq. (11)) and SBM model (Eq. (13)); we can obtain the aggregate TE of each DMU. Then, we use the BCC model to analyze the PTE and SE of each DMU. For efficient DMUs, the efficiency scores are equal to one, and inefficient DMUs have efficiency scores less than one. The results from the DEA model of the semiconductor industry companies can be divided into groups of efficient DMUs and inefficient DMUs.

\subsection{VIKOR-IGE model}

There are numerous multiple criteria decision making (MCDM) methods (Guitouni, Martel 1998). Among which, the VIKOR and TOPSIS methods are based on the concept of compromise solutions (Opricovic, Tzeng 2004). It is known that the TOPSIS method can not correctly reflect the distance from each object to positive-ideal solution and negative-ideal solution (Opricovic, Tzeng 2004). Olson (2004) mentioned TOPSIS method using the m-dimensional Euclidean distance to calculate the separation measure is not appropriate. VIKOR has advantages which can determine a compromise solution to reflect the attitude of most decision-makers for the decision-making problem. Therefore, this study applied the VIKOR method (Azimi et al. 2011; Chang, Hsu 2009; Opricovic 1998; Opricovic, Tzeng 2004, 2007) to improve its shortcomings and increase the validity of the model.

However, the disadvantage of traditional VIKOR is that selecting the evaluation criteria and the weight of the decision has a significant influence on the results of evaluation. Therefore, in this study a combined VIKOR method based on globalized IGRA and entropy weight was proposed for improving the above-mentioned disadvantages. Globalized IGRA (Section 2.1) is used to select the representative indicators for evaluating performance, and the entropy weight is used to obtain the weights of all evaluation criteria in the VIKOR method. Thus, the proposed VIKOR-IGE model can be summarized as follows:

Step 1. Selecting representative performance indicators to use in the VIKOR based on the entropy weight model: In this study, we first calculate the grey relational grades between the performance indicators (Eqs (5)-(7)). According to the value of grey relational grade, we can partition performance indicators into several groups by threshold value. Then, choose one from each group as a representative indicator. 
Step 2. Construct the normalized decision matrix: The results from the DEA model indicate groups of efficient and inefficient companies respectively. Then, according to the selected representative indicators, we obtain the normalized decision matrix after normalization by Eqs (1)-(3),

$$
F=\left[\gamma_{i j}\right]_{m \times n}, i=1,2, \ldots, m, j=1,2, \ldots, n,
$$

where $\gamma_{i j}$ denotes the performance evaluation value of the $i$ th evaluating object on the $j$ th indicator, the same as in Eq. (8).

Step 3. Determine the positive ideal solution $\left(f^{*}\right)$ and the negative ideal solution $\left(f^{-}\right)$for all evaluation criteria. Then the ideal solution set $f^{\star}$ and $f^{-}$can be expressed as:

$$
\begin{aligned}
& f_{i}^{*}=\left[\left(\max _{j} \gamma_{i j} \mid i \in I_{1}\right),\left(\min _{j} \gamma_{i j} \mid i \in I_{2}\right)\right], \forall_{i} ; \\
& f_{i}^{-}=\left[\left(\min _{j} \gamma_{i j} \mid i \in I_{1}\right),\left(\max _{j} \gamma_{i j} \mid i \in I_{2}\right)\right], \forall_{i},
\end{aligned}
$$

where $I_{1}$ is associated with benefit criteria, and $I_{2}$ is related to the cost criteria.

Step 4. Calculate the criteria weights using the entropy weight method: There are a lot of methods for calculating the weight. In order to avoid the influence of subjective factors of the decision-maker, this study uses the entropy weight method to find the weight of each criterion. We use the normalized decision matrix $F$ to calculate the entropy weight of each evaluation criterion by using Eqs (8)-(10).

Step 5. Calculate the utility measure and regret measure: The utility measure $\left(S_{j}\right)$ and the regret measure $\left(R_{j}\right)$ for each $j$ th indicator are given as:

$$
\begin{gathered}
S_{j}=\sum_{i=1}^{n} w_{i}\left(f_{i}^{*}-f_{i j}\right) /\left(f_{i}^{*}-f_{i}^{-}\right) ; \\
R_{j}=\max _{i}\left[w_{i}\left(f_{i}^{*}-f_{i j}\right) /\left(f_{i}^{*}-f_{i}^{-}\right)\right], j=1,2, \ldots J .
\end{gathered}
$$

Step 6. Calculate the VIKOR index $Q$ : The VIKOR index of the $j$ th evaluating object can be expressed as:

$$
Q_{j}=v\left[\frac{S_{j}-S^{*}}{S^{-}-S^{*}}\right]+(1-v)\left[\frac{R_{j}-R^{*}}{R^{-}-R^{*}}\right],
$$

where: $S^{*}=\min _{j} S_{j}, S^{-}=\max _{j} S_{j}, R^{*}=\min _{j} R_{j}, R^{-}=\max _{j} R_{j}$. The $v$ is the coefficient for the decision-making mechanism, and is usually taken as 0.5 (Purjavad, Shirouyehzad 2011).

Step 7. VIKOR index ranking: The evaluation objects are ranked according to the values of $Q_{j}, S_{j}$, and $R_{j}$. When the following two conditions are satisfied, then we can rank the evaluation objects ( $Q_{j}$ is the smaller the better) according to the value of $Q_{j}$.

Condition 1. Acceptable advantage: The threshold condition for acceptable advantage is:

$$
Q^{\prime \prime}-Q^{\prime} \geq 1 /(J-1)
$$

where $Q^{\prime}$ denotes the $Q$ value that is ranked first, $Q^{\prime \prime}$ denotes the $Q$ value that is ranked second, and $J$ is the number of evaluation objects. 
Condition 2. Acceptable stability in decision-making: According to the rank of $Q$, the first ranked $S(R)$ value must be higher than the second ranked $S(R)$ value.

If one of the above conditions is not satisfied, then we can get the compromised solution by following the judge rules. That is, when the first and second ranked objects satisfy both condition 1 and condition 2, then the first ranked object is the best object. If the first and second ranked objects only fail to satisfy condition 2 , then the first and second ranked objects are the best objects simultaneously. When condition 1 is not satisfied, then objective $M$ is determined by $Q^{M}-Q^{\prime} \geq 1 /(J-1)$ as the maximum $M$. At this point, objective 1 to $M$ shall be taken as the compromised solutions, which are the best objects simultaneously.

\section{Empirical results}

\subsection{Efficiency analysis with the DEA-IG model}

In order to measure the operating efficiency of DMUs, this study proposes a DEA-IG model combined IGRA and DEA as described below.

\subsubsection{Determining DMUs and data source}

Using DEA for efficiency analysis, when selecting a different member of DMUs, input and output variables will yield different efficiency values. Therefore, the DMUs selected must be homogeneous and under the same market condition to avoid distortion of the assessment results. In addition, when selecting the number of DMUs, Golany and Roll (1989) established a rule of thumb that the number of the assessed units should be at least twice the sum of the number of input and output variables.

Semiconductors have played an important role in today's high-tech industry, and after the twenty-first century, the semiconductor industry is widely regarded as an important investment (Hung, Lu 2008). The output value of Taiwan's semiconductor industry has reached approximately $20 \%$ of the global semiconductor industry, giving Taiwan a very important position in the global market. In Taiwan, the semiconductor industry is a direction of future high-technology investment development and also the major recipient of investment projects. Therefore, this study takes listed semiconductor companies in Taiwan as a case to verify the developed decision-making process.

Within DEA procedure, we first need to determine the DMUs. This study chooses the listed companies in the Taiwan's semiconductor industry (including integrated circuit (IC) design, manufacturing, packaging, and testing companies) as a sample. Companies with missing or incomplete data were excluded. The total number of listed semiconductor companies used in this study is 38 , and we include 14 IC design companies (36, 8\%), 11 IC fabrication companies (29.0\%), 13 IC packaging and testing companies (34.2\%), which are taken as DMUs. The input and output variables and financial data of Taiwan's semiconductor companies in 2010 were collected from the Taiwan Economic Journal (TEJ) database. 


\subsubsection{Selection of input and output variables}

The selection of input and output variables is the most important issue for the application of DEA (Morita, Avkiran 2009). According to the recommendation of Golany and Roll (1989), this study followed past research and stayed within the characteristics of the semiconductor industry to select the input and output variables. The input variables include the following: (1) R\&D expenses (Chang et al. 2011; Ho et al. 2011); (2) Administrative expenses (Chang et al. 2011; Zou, Huan 2011); (3) Fixed assets (Zou, Huan 2011); (4) Selling expenses (Ho et al. 2011); (5) Number of employees (Chang et al. 2011; Zou, Huan 2011); (6) Inventory (Lee, Park 2005); (7) Operating expenses (Eken, Kale 2011; Ho et al. 2011); (8) Total debt (Diskaya et al. 2011); and (9) Total assets (Duran, Zehir 2011; Halkos, Tzeremes 2012; Ho et al. 2011).

Moreover, the output variables include the total revenue (Chiu, Huang 2011; Shuai, Wu 2011), net sales (Duran, Zehir 2011; Tsai 2011; Wang et al. 2011), net profit ratio (Lee, Pai 2011), operating income (Long, Li 2011; Wang et al. 2011) and gross profit margin (Duran, Zehir 2011).

\subsubsection{The result of the DEA-IG model}

In this study, the CCR, BCC and SBM models were used to evaluate the technical efficiency (TE), pure technical efficiency (PTE), and scale efficiency (SE) of the listed semiconductor companies in Taiwan in 2010. The DEA software DEAP 2.1 (Coelli 1996) and DEA Excel Solver (Zhu 2003) were used to calculate a company's relative efficiency. The results of efficiency analysis can indicate whether a company is relatively efficient or inefficient.

First, we need to select the representative indicators from nine input and five output variables (Table 2), respectively. We also need to ensure that DEA efficiency analysis can effectively show the listed semiconductor company's operating performance. Therefore, this study uses the globalized IGRA method (Section 2.1) to calculate the maximum eigenvalue $\lambda_{\max }$ of input and output variables as 8.461 and 4.367 , respectively. Then we can calculate the eigenvector for each variable. The results are shown in Table 2 . In this study, variables with eigenvectors greater than 0.335 and 0.47 were used to form the representative input and output variables, respectively. The selected input variables include total assets, operating expenses, administrative expenses, inventory, and the selected output variables are total revenue and net sales.

Table 2. The selection of input and output variables based on the globalized GRA

\begin{tabular}{lcclcc}
\hline & \multicolumn{2}{c}{ Input } & \multicolumn{2}{c}{ Output } \\
\hline Variable & Eigenvector & Selected & Variable & Eigenvector & Selected \\
\hline Number of employees & 0.331 & & Total revenue & 0.470 & $*$ \\
\hline Fixed assets & 0.334 & & Net sales & 0.471 & $*$ \\
\hline Total asset & 0.338 & $\star$ & Net profit ratio & 0.466 & \\
\hline Total debt & 0.328 & & Gross profit margin & 0.349 & \\
\hline Operating expenses & 0.338 & $*$ & Operating income & 0.467 & \\
\hline Selling expenses & 0.329 & & & & \\
\hline Administrative expenses & 0.337 & $*$ & & & \\
\hline R\&D expenses & 0.329 & & & & \\
\hline Inventory & 0.335 & $*$ & & &
\end{tabular}


Then, the selected four inputs and two outputs were used in the DEA efficiency analysis of 38 listed semiconductor companies in Taiwan. When using DEA to evaluate operating efficiency, the input and output variables should confirm to isotonicity (i.e. the input and output variables are all positively correlated) (Avkiran 1999). That is, when higher levels of input lead to higher levels of output, the operating efficiency factor should be positive. Table 3 shows the Spearman correlation coefficients between input and output variables. The results indicate that a statistically significant positive correlation was obtained, and the isotonicity test was passed.

Table 3. Spearman's correlation coefficients between input and output variables

\begin{tabular}{|c|c|c|c|c|c|}
\hline & 1 & 2 & 3 & 4 & 5 \\
\hline \multicolumn{6}{|l|}{ 1. Total revenue } \\
\hline 2. Net sales & $0.995^{\star *}$ & & & & \\
\hline 3. Total asset & $0.933^{\star *}$ & $0.910^{\star \star}$ & & & \\
\hline 4. Operating expenses & $0.830^{\star \star}$ & $0.797^{\star \star}$ & $0.942^{\star \star}$ & & \\
\hline 5. Administrative expenses & $0.917^{\star *}$ & $0.902^{\star *}$ & $0.936^{\star *}$ & $0.950^{\star *}$ & \\
\hline 6. Inventory & $0.798^{\star \star}$ & $0.770^{\star \star}$ & $0.906^{\star \star}$ & $0.977^{\star \star}$ & $0.951^{\star \star}$ \\
\hline
\end{tabular}

${ }^{* *}: p<0.01$

Standard DEA can be modeled in two ways, input oriented (control for the input variables), and output oriented (control for the output variables) DEA models (Ray 2004). From the business point of view of a company, it is easy to reduce input rather than increase output. Thus, this study used the input oriented DEA model to obtain the relative operational efficiency of the semiconductor companies. The CCR, BCC and SBM models are used to evaluate the relative operational efficiency of 38 Taiwan semiconductor companies in 2010.

The three calculated efficiency scores (TE, PTE and SE) are given in Table 4. The TE scores can be obtained from the input oriented CCR model (Charnes et al. 1978) and input oriented SBM model (Tone 2001). The PTE score can be obtained from the input oriented BCC model (Banker et al. 1984), and SE can be computed by SE=TE/PTE. A TE score equal to one implies full efficiency. In contrast, if the score is less than one, it indicates technical inefficiency. If the PTE score of a company is equal to one, then the company is considered as efficient. If the value of PTE is less than one, then the company is operating under pure technical inefficiency. When the value of SE is equal to one, it implies the company is operating under constant return to scale (CRS). If the SE is less than one, the company is scaled as inefficient; it will be under increasing return to scale (IRS) or decreasing return to scale (DRS). Therefore, efficient companies (DMUs) are identified by an efficiency score equal to 1 . Table 4 shows that only 11 companies were relatively efficient and the remaining 27 were inefficient, i.e. their TE and PTE scores were below 1 . The average values of TE obtained from the CCR and SBM were 0.850 and 0.743 , respectively; PTE and SE were found to be $0.797,0.86$ and 0.925 , respectively. Table 4 also provides the returns to scale information of each inefficient company. We find that 8 companies show IRS, and 18 companies show DRS. 
Table 4. Efficiency values of companies based on CCR and BCC models

\begin{tabular}{|c|c|c|c|c|c|}
\hline $\begin{array}{c}\text { DMU } \\
\text { (Company) }\end{array}$ & $\begin{array}{l}\text { CCR } \\
\text { (TE) }\end{array}$ & $\begin{array}{c}\text { BCC } \\
\text { (PTE) }\end{array}$ & $\begin{array}{l}\text { Scale } \\
\text { (SE) }\end{array}$ & $\begin{array}{l}\text { SBM } \\
\text { (TE) }\end{array}$ & $\begin{array}{l}\text { Returns } \\
\text { to scale }\end{array}$ \\
\hline $\mathrm{F} 1$ & 0.650 & 0.720 & 0.903 & 0.431 & DRS \\
\hline F2 & 1.000 & 1.000 & 1.000 & 1.000 & CRS \\
\hline F3 & 0.605 & 0.764 & 0.791 & 0.475 & DRS \\
\hline $\mathrm{F} 4$ & 0.786 & 0.799 & 0.984 & 0.661 & DRS \\
\hline F5 & 0.843 & 1.000 & 0.843 & 0.752 & IRS \\
\hline F6 & 1.000 & 1.000 & 1.000 & 1.000 & CRS \\
\hline F7 & 0.851 & 0.879 & 0.968 & 0.664 & DRS \\
\hline F8 & 1.000 & 1.000 & 1.000 & 1.000 & CRS \\
\hline F9 & 0.715 & 0.764 & 0.937 & 0.547 & DRS \\
\hline F10 & 1.000 & 1.000 & 1.000 & 1.000 & CRS \\
\hline F11 & 0.898 & 0.963 & 0.933 & 0.706 & DRS \\
\hline F12 & 0.766 & 1.000 & 0.766 & 0.611 & DRS \\
\hline F13 & 0.863 & 0.865 & 0.999 & 0.636 & IRS \\
\hline F14 & 1.000 & 1.000 & 1.000 & 1.000 & CRS \\
\hline F15 & 0.832 & 0.914 & 0.910 & 0.675 & DRS \\
\hline F16 & 1.000 & 1.000 & 1.000 & 1.000 & CRS \\
\hline F17 & 0.671 & 1.000 & 0.671 & 0.505 & DRS \\
\hline F18 & 0.686 & 0.687 & 0.999 & 0.624 & IRS \\
\hline F19 & 0.837 & 0.844 & 0.992 & 0.701 & DRS \\
\hline F20 & 0.984 & 1.000 & 0.984 & 0.660 & DRS \\
\hline F21 & 0.634 & 0.663 & 0.956 & 0.562 & IRS \\
\hline F22 & 1.000 & 1.000 & 1.000 & 1.000 & CRS \\
\hline F23 & 0.734 & 0.742 & 0.989 & 0.623 & DRS \\
\hline F24 & 0.999 & 0.999 & 1.000 & 0.864 & DRS \\
\hline F25 & 0.710 & 0.714 & 0.995 & 0.650 & DRS \\
\hline F26 & 0.857 & 1.000 & 0.857 & 0.698 & DRS \\
\hline F27 & 0.994 & 1.000 & 0.994 & 0.942 & DRS \\
\hline F28 & 0.772 & 0.776 & 0.994 & 0.724 & IRS \\
\hline F29 & 1.000 & 1.000 & 1.000 & 1.000 & CRS \\
\hline F30 & 0.845 & 0.859 & 0.983 & 0.737 & IRS \\
\hline F31 & 0.686 & 0.937 & 0.732 & 0.595 & DRS \\
\hline F32 & 0.707 & 0.804 & 0.880 & 0.536 & IRS \\
\hline F33 & 1.000 & 1.000 & 1.000 & 1.000 & CRS \\
\hline F34 & 1.000 & 1.000 & 1.000 & 0.750 & CRS \\
\hline F35 & 0.654 & 1.000 & 0.654 & 0.389 & IRS \\
\hline F36 & 1.000 & 1.000 & 1.000 & 1.000 & CRS \\
\hline F37 & 0.727 & 1.000 & 0.727 & 0.500 & DRS \\
\hline F38 & 1.000 & 1.000 & 1.000 & 1.000 & CRS \\
\hline Mean & 0.850 & 0.913 & 0.933 & 0.743 & \\
\hline
\end{tabular}

CCR: constant returns to scale (total technical efficiency, TE), BCC: variable returns to scale (pure technical efficiency, PTE), scale: scale efficiency (SE), SBM: slack-based measure, DRS: decreasing return to scale, CRS: constant return to scale, IRS: increasing return to scale. 


\subsection{The results of performance evaluation with the VIKOR-IGE model}

For performance evaluation, this study proposed a VIKOR-IGE model which combines globalized IGRA, the entropy weight method and the VIKOR method to evaluate the performance of 38 listed semiconductor companies in Taiwan (F1 to F38), as described below.

\subsubsection{Using GRA to select the representative indicators for performance evaluation}

In this study, two types of indicators concerning performance are applied to evaluate the companies. Both financial and non-financial performance indicators are used to evaluate company's performance. We use the selected output variables in Section 2.1.2, total revenue and net sales, as non-financial performance criteria. Three types of financial categories, profitability, solvency and operating ability are used to measure financial performance. 17 financial indicators were selected, as defined in Table 5. As listed in Table 5, the most critical of the

Table 5. The financial indicators on three categories

\begin{tabular}{|c|c|c|c|c|}
\hline Category & Code & Financial ratios & Definition & Target \\
\hline \multirow[t]{5}{*}{ Profitability } & P1 & Returns on assets (ROA) & $\begin{array}{l}\text { [Earning }+ \text { interest expenses } \times(1 \text {-tax rate })] / \\
\text { Average total assets }\end{array}$ & Max \\
\hline & $\mathrm{P} 2$ & Returns on equity (ROE) & Current term net profit/Shareholder equity & $\operatorname{Max}$ \\
\hline & P3 & Operating profit margin & Operating profit/Operating revenue & Max \\
\hline & $\mathrm{P} 4$ & Net profit margin after tax & Net profit after tax/Operating revenue & Max \\
\hline & P5 & Earnings per share & $\begin{array}{l}\text { Total profits of a company/ } \\
\text { Number of shares }\end{array}$ & Max \\
\hline \multirow{6}{*}{$\begin{array}{l}\text { Operating } \\
\text { ability }\end{array}$} & $\mathrm{O} 1$ & Total assets turnover & Net operating revenue/Total assets & Max \\
\hline & $\mathrm{O} 2$ & Accounts receivable turnover & $\begin{array}{l}\text { Net sales/Average balance of account } \\
\text { receivable }\end{array}$ & $\operatorname{Max}$ \\
\hline & $\mathrm{O} 3$ & Inventory turnover & Cost of sales/Average inventory & Max \\
\hline & $\mathrm{O} 4$ & Average daily sales & 365/Inventory turnover & Min \\
\hline & O5 & Fixed assets turnover & Net operating revenue/Total fixed assets & Max \\
\hline & O6 & Shareholder equity turnover & Operating revenue/Shareholder equity & Max \\
\hline \multirow[t]{6}{*}{ Solvency } & S1 & Current ratio & Current assets/Current liabilities & Max \\
\hline & S2 & Quick ratio & $\begin{array}{l}\text { (Current assets - Inventories)/ } \\
\text { Current liabilities }\end{array}$ & $\operatorname{Max}$ \\
\hline & S3 & Debt ratio & Total debt/Total assets & Min \\
\hline & S4 & Long-term capital ratio & $\begin{array}{l}\text { (Net shareholder's equity + Long-term } \\
\text { liabilities)/Net fixed assets }\end{array}$ & $\operatorname{Max}$ \\
\hline & S5 & Cash flow ratio & $\begin{array}{l}\text { Net cash provided by operating activities/ } \\
\text { Current liabilities }\end{array}$ & Max \\
\hline & S6 & Cash reinvestment ratio & $\begin{array}{l}\text { (Net cash flow from operating activities- } \\
\text { cash dividend)/(Total fixed assets }+ \\
\text { Long-term investments + Other assets + } \\
\text { Working capital) }\end{array}$ & Max \\
\hline
\end{tabular}


financial indicators are the larger the better (Target: Max), but some are the smaller the better (Target: Min). Financial indicators have different attributes. Wang $(2008,2009)$ mentioned that the use of representative financial indicators to evaluate the financial performance of a company is a MCDM problem, and selecting the representative financial indicators plays a very important role in the performance evaluation of companies.

This study based on the work of Feng and Wang (2000) and Wang $(2008,2009)$ who proposed a method to select the representative financial indicators. That is, first using the globalized IGRA to cluster financial indicators from three categories into several groups. Then, calculate the total score according to the ranking results. The total score which is the highest is selected as the representative financial indicator of the group.

First, according to the data type of the 17 financial indicators in Table 5, the larger the better (i.e. target is max) and the smaller the better (i.e. target is min), by using Eqs (1)-(3) we normalize the 17 financial data for three categories, respectively. When the distinguishing coefficient $\varsigma$ and the adjustment coefficient $\eta$ are set to 0.5 , by Eqs (4)-(6), we can obtain three categories of the grey correlation matrix, as shown in Table 6.

We set the threshold value as 0.7 (Feng, Wang 2000; Wang 2008, 2009) to cluster financial indicators in three categories. The clustering results are shown in Table 7. Table 7 shows that profitability category is divided into two groups. The representative financial indicators we selected were P1 (ROA) and P4 (net profit margin after tax). The operating ability category is divided into four groups and selected representative financial indicators were $\mathrm{O} 2$ (accounts

Table 6. The grey correlation matrix on three categories

\begin{tabular}{|c|c|c|c|c|c|c|}
\hline & \multicolumn{6}{|c|}{ Profitability } \\
\hline & $\mathrm{P} 1$ & $\mathrm{P} 2$ & P3 & $\mathrm{P} 4$ & P5 & \\
\hline P1 & 1 & 0.7755 & 0.6388 & 0.6470 & 0.6518 & \\
\hline P2 & 0.7755 & 1 & 0.3770 & 0.3791 & 0.3803 & \\
\hline P3 & 0.6388 & 0.3770 & 1 & 0.9797 & 0.9679 & \\
\hline $\mathrm{P} 4$ & 0.6596 & 0.4037 & 0.9803 & 1 & 0.9863 & \\
\hline \multirow[t]{3}{*}{ P5 } & 0.6705 & 0.4181 & 0.9693 & 0.9865 & 1 & \\
\hline & \multicolumn{6}{|c|}{ Operating ability } \\
\hline & O1 & $\mathrm{O} 2$ & $\mathrm{O} 3$ & $\mathrm{O} 4$ & O5 & O6 \\
\hline $\mathrm{O} 1$ & 1 & 0.7446 & 0.6907 & 0.7492 & 0.6755 & 0.8189 \\
\hline $\mathrm{O} 2$ & 0.7383 & 1 & 0.8004 & 0.6832 & 0.8011 & 0.7918 \\
\hline $\mathrm{O} 3$ & 0.6693 & 0.7918 & 1 & 0.6795 & 0.8361 & 0.8245 \\
\hline $\mathrm{O} 4$ & 0.7313 & 0.6678 & 0.6795 & 1 & 0.5750 & 0.7058 \\
\hline O5 & 0.6544 & 0.7949 & 0.8377 & 0.5795 & 1 & 0.7858 \\
\hline \multirow[t]{3}{*}{ O6 } & 0.8092 & 0.7894 & 0.8294 & 0.7024 & 0.7909 & 1 \\
\hline & \multicolumn{6}{|c|}{ Solvency } \\
\hline & S1 & S2 & S3 & S4 & S5 & S6 \\
\hline S1 & 1 & 0.9687 & 0.7357 & 0.8130 & 0.7189 & 0.6263 \\
\hline S2 & 0.9696 & 1 & 0.7198 & 0.8255 & 0.7242 & 0.6234 \\
\hline S3 & 0.7153 & 0.6882 & 1 & 0.5550 & 0.8130 & 0.7794 \\
\hline S4 & 0.7892 & 0.7959 & 0.5315 & 1 & 0.5796 & 0.4815 \\
\hline S5 & 0.6829 & 0.6784 & 0.8048 & 0.5796 & 1 & 0.8482 \\
\hline S6 & 0.5585 & 0.5542 & 0.7696 & 0.4535 & 0.8482 & 1 \\
\hline
\end{tabular}


receivable turnover), O3 (inventory turnover), O4 (average daily sales) and O6 (shareholder equity turnover). As for the solvency category, it is divided into three groups and selected representative financial indicators were S2 (quick ratio), S3 (debt ratio) and S5 (cash flow ratio). After the 9 representative financial indicators were selected, we then added the non-financial indicators of "total revenue" (TR) and "net sales" (NS), which have a total of 11 evaluation criteria to conduct a comprehensive performance evaluation and ranking for the 38 listed semiconductor companies in Taiwan.

Table 7. The classification of financial indicators and select the representative indicators

\begin{tabular}{llll}
\hline Category & Cluster & $\begin{array}{l}\text { Financial indicators } \\
\text { within the cluster }\end{array}$ & $\begin{array}{l}\text { Representative indicators } \\
\text { of each cluster }\end{array}$ \\
\hline Profitability & C1 & P1, P2 & P1: ROA \\
\cline { 2 - 4 } & C2 & P3, P4, P5 & P4: Net profit margin after tax \\
\hline $\begin{array}{l}\text { Operating } \\
\text { ability }\end{array}$ & C3 & O2 & O2: Accounts receivable turnover \\
\cline { 2 - 4 } & C4 & O4 & O4: Average daily sales \\
\cline { 2 - 4 } & C5 & O6 & O6: Shareholder equity turnover \\
\cline { 2 - 4 } Solvency & C7 & O1, O3, O5 & O3: Inventory turnover \\
\cline { 2 - 4 } & C8 & S3 & S3: Debt ratio \\
\cline { 2 - 4 } & C9 & S4, S5, S6 & S2: Current ratio \\
\hline
\end{tabular}

\subsubsection{Calculation of the weights of the evaluation indicators with the entropy method}

First, we normalize the 11 performance evaluation indicators using Eqs (1)-(3) to obtain the normalization matrix (Eq. (7)). Then, according to Eqs (7)-(10), we can obtain the entropy weights of the 11 performance evaluation indicators. Table 8 shows the results of the entropy weights for the efficient company and inefficient company groups, respectively. From the results in Table 8, we observe that the TR (total revenue) is the most important variable influencing a semiconductor company's performance, followed by NS (net sales).

Table 8. Results of the entropy weight for the 11 representative indicators

\begin{tabular}{lccccccccccc}
\hline \multicolumn{1}{c}{ Group } & $\mathrm{P} 1$ & $\mathrm{P} 4$ & $\mathrm{O} 2$ & $\mathrm{O} 3$ & $\mathrm{O} 4$ & $\mathrm{O} 6$ & $\mathrm{~S} 2$ & $\mathrm{~S} 3$ & $\mathrm{~S} 5$ & $\mathrm{TR}$ & $\mathrm{NS}$ \\
\hline $\begin{array}{l}\text { Efficient } \\
\text { company }\end{array}$ & 0.0888 & 0.0911 & 0.0886 & 0.0880 & 0.0863 & 0.0889 & 0.0885 & 0.0887 & 0.0889 & 0.1018 & 0.1005 \\
\hline $\begin{array}{l}\text { Inefficient } \\
\text { company }\end{array}$ & 0.0895 & 0.0893 & 0.0900 & 0.0913 & 0.0895 & 0.0902 & 0.0907 & 0.0895 & 0.0896 & 0.0959 & 0.0945 \\
\hline
\end{tabular}

\subsubsection{The results of performance evaluation with the VIKOR-IGE model}

In order to evaluate the performance and rank the 38 listed semiconductor companies (F1 to F38), this study proposes using a VIKOR-IGE model to evaluate the operating performance of the efficient and inefficient company groups, respectively. According to Section 2.4, we can construct the VIKOR-IGE model by using the following steps: 
Step 1: According to the results of the globalized IGRA in Section 3.2.1, we select 9 representative financial indicators. From the results of the DEA-IG model in Section 3.1.3, we select two representative output variables. Therefore, this study uses 11 indicators to establish a performance evaluation model of the 38 semiconductor companies.

Step 2: Determine the ideal and negative ideal solution for efficient and inefficient companies, respectively.

Efficient companies group:

$\begin{array}{cllllllllll}\mathrm{P} 1 & \mathrm{P} 4 & \mathrm{O} 2 & \mathrm{O} 3 & \mathrm{O} 4 & \mathrm{O} 6 & \mathrm{~S} 2 & \mathrm{~S} 3 & \mathrm{~S} 5 & \mathrm{TR} & \mathrm{N} \\ f_{i}^{*}=\{24.76, & 293.54, & 15.73, & 20.95, & 133.74, & 2.77, & 389.4, & 62.56, & 186.28, & 406963311, & 419537911\} \\ f_{i}^{-}=\{-7.29, & -22.99, & 3.73, & 2.73, & 17.42, & 0.78, & 35.4, & 17.16, & -65.2, & 4189005, & 3100141\}\end{array}$

Inefficient companies group:

$f_{i}^{*}=\{14.16, \quad 37.53, \quad 11.61,49.28,122.03,2.98,797.98,75.24,183.97,120430736188742797\}$

$f_{i}^{-}=\left\{\begin{array}{llllllll}-10.54,-37.5, \quad 3.08, & 0, & 0, & 0.21,27.92, & 4.4, & -72.67,226794 & 277339\end{array}\right.$

Step 3: Use Eqs (8)-(10) to calculate the entropy weight of 11 indicators. The results are shown in Table 8.

Step 4: Compute the values of $S_{j}, R_{j}$ and $Q_{j}\left(Q_{j}\right.$ is measured with $\left.v=0.5\right)$ for each company, by using Eqs (14)-(19). The results are shown in Table 9.

Step 5: According to Table 9, we separate and rank the efficient and inefficient companies, sorting by the values of $S_{j}, R_{j}$ and $Q_{j}$. From the acceptable advantage, we can calculate the threshold values (Eq. (20)) as 0.1 and 0.0385 for the efficient and inefficient companies, respectively. The values of $S, R$ and $Q$ for the efficient and inefficient companies calculated by VIKOR-IGE model are shown in Table 9 . When ranking by the VIKOR method in accordance with the $Q$ values, the lower the value the better the performance of the company.

To rank the 38 semiconductor companies using the VIKOR-IGE model, we had to examine the $S, R$ and $Q$ values of each company, to see whether conditions 1 and 2 (Section 2.4) are satisfied. According to the results (Table 9) for the efficient companies in Taiwan for 2010, company F6 had the lowest value of $Q$, followed by company F16. However, company F6 did not have an acceptable advantage. This is because $Q^{[F 16]}-Q^{[F 6]}=0.0775<0.1$. On the other hand, we observed that company F6 was acceptably stable in the decision-making process. Therefore, we proposed F6 and F16 as a set of compromise solutions. By comparing the $S, R$ and $Q$ values of each company, we can obtain the sorting result of the efficient companies, and cluster them into seven groups. The ranking is:

$$
F 6 \approx F 16 \succ F 10 \approx F 36 \succ F 2 \approx F 8 \approx F 14 \approx F 22 \approx F 33 \approx F 38 \succ F 29,
$$

where: $A \succ B$ indicates that $A$ is preferred to $B ; A \approx B$ indicates that $A$ and $B$ are a set of compromise solutions. In addition, the inefficient companies can be clustered into 10 groups. The ranking is:

$$
\begin{aligned}
& F 26 \succ F 27 \succ F 23 \succ F 25 \approx F 31 \succ F 15 \approx F 18 \approx F 19 \approx F 21 \succ F 4 \approx F 7 \approx F 12 \approx F 28 \approx \\
& F 37 \succ F 11 \approx F 24 \succ F 1 \approx F 3 \approx F 9 \approx F 13 \approx F 20 \succ F 5 \approx F 17 \approx F 32 \succ F 34 \succ F 35 .
\end{aligned}
$$


Table 9. The values of $S, R$ and $Q$ for efficient and inefficient companies groups

\begin{tabular}{|c|c|c|c|c|c|c|c|}
\hline \multicolumn{4}{|c|}{ Efficiency company group } & \multicolumn{4}{|c|}{ Inefficiency company group } \\
\hline Company & $S_{j}$ & $R_{j}$ & $Q_{j}$ & Company & $S_{j}$ & $R_{j}$ & $Q_{j}$ \\
\hline F2 & 0.7337 & 0.0973 & 0.7929 & F1 & 0.6592 & 0.0947 & 0.8187 \\
\hline F6 & 0.4796 & 0.0850 & 0.0383 & F3 & 0.6851 & 0.0932 & 0.8146 \\
\hline F8 & 0.7024 & 0.1011 & 0.8594 & $\mathrm{~F} 4$ & 0.6527 & 0.0898 & 0.6867 \\
\hline F10 & 0.6947 & 0.0937 & 0.6282 & F5 & 0.6751 & 0.0949 & 0.8451 \\
\hline F14 & 0.6569 & 0.1018 & 0.8105 & F7 & 0.5919 & 0.0929 & 0.6807 \\
\hline F16 & 0.4547 & 0.0889 & 0.1158 & F9 & 0.6565 & 0.0940 & 0.7959 \\
\hline F22 & 0.7804 & 0.0958 & 0.8200 & F11 & 0.6379 & 0.0927 & 0.7391 \\
\hline F29 & 0.7232 & 0.1013 & 0.8959 & F12 & 0.5571 & 0.0940 & 0.6604 \\
\hline F33 & 0.6589 & 0.1009 & 0.7862 & F13 & 0.6769 & 0.0937 & 0.8175 \\
\hline F36 & 0.6451 & 0.0935 & 0.5466 & F15 & 0.4982 & 0.0782 & 0.6305 \\
\hline \multirow[t]{17}{*}{ F38 } & 0.7115 & 0.1005 & 0.8534 & F17 & 0.5529 & 0.0842 & 0.8550 \\
\hline & & & & F18 & 0.7480 & 0.0936 & 0.6091 \\
\hline & & & & F19 & 0.5731 & 0.0853 & 0.6282 \\
\hline & & & & F20 & 0.6881 & 0.0902 & 0.7853 \\
\hline & & & & F21 & 0.6479 & 0.0948 & 0.6217 \\
\hline & & & & F23 & 0.6548 & 0.0908 & 0.4582 \\
\hline & & & & F24 & 0.6161 & 0.0934 & 0.7258 \\
\hline & & & & F25 & 0.5966 & 0.0879 & 0.5627 \\
\hline & & & & F26 & 0.4028 & 0.0822 & 0.1559 \\
\hline & & & & F27 & 0.5855 & 0.0760 & 0.2486 \\
\hline & & & & F28 & 0.6214 & 0.0907 & 0.6651 \\
\hline & & & & F30 & 0.5995 & 0.0926 & 0.6831 \\
\hline & & & & F31 & 0.6104 & 0.0871 & 0.5607 \\
\hline & & & & F32 & 0.6759 & 0.0947 & 0.8411 \\
\hline & & & & F34 & 0.7117 & 0.0958 & 0.9164 \\
\hline & & & & F35 & 0.7702 & 0.0959 & 1.0000 \\
\hline & & & & F37 & 0.5703 & 0.0936 & 0.6695 \\
\hline
\end{tabular}

According to the results of compromise solutions, the rankings of efficient and inefficient companies are shown in Table 10, respectively.

According to the ranking results in Table 10, the 11 efficient companies are divided into 1-4 grades, in which company F6 and F16 had the best operating performance among the 11 efficient companies, followed by company F10, F36 and finally, company F29. As for the 27 inefficient companies that can be divided into 1-11 grades, company F26 had the best operating performance among 27 listed inefficient companies, followed by company F35. Company F3 had the worst operating performance.

From an investor's perspective, efficient companies should be the first choice when making an investment decision. In view of this, companies F6 and F16 are the best choice in this group. If investors want to choose one of the inefficient companies to invest in, it is 
Table 10. The ranking results of efficiency and inefficiency company groups

\begin{tabular}{clcl}
\hline & Efficiency company group & & Inefficiency company group \\
\hline Rank & Company & Rank & Company \\
\hline 1 & F6, F16 & 1 & F26 \\
\hline 2 & F10, F36 & 2 & F27 \\
\hline 3 & F2, F8, F14, F22, F33, F38 & 3 & F23 \\
\hline 4 & F29 & 4 & F25, F31 \\
\hline & 5 & F15, F18, F19, F21 \\
\hline & 6 & F4, F7, F12, F28, F37, F30 \\
\hline & 7 & F11, F24 \\
\hline & 8 & F1, F3, F9, F13, F20 \\
\hline & 9 & F5, F17, F32 \\
\hline & 10 & F34 \\
\hline
\end{tabular}

recommended that they select the more highly ranked, such as companies F23, F25, F26, F27 and F31. Investors should avoid investing companies with inefficient and poor operating performance, such as companies F34 and F35. In particular, company F35 ranked last among the 27 inefficient companies in operating performance, showing that due to the company's production inefficiency, inefficient allocation of resources and poor operating performance, a management crisis will most likely occur. Therefore, investors should avoid investing in this company. Company F35's managers should understand their position in Taiwan's semiconductor industry, increase its resource allocation efficiency and improve operating performance, to achieve the goal of sustainable management.

\section{Conclusions}

In order to enable a company to achieve sustainable management, apart from making the most efficient use of resources, it is more important to ensure that the company can move toward better business performance. Evaluation of operating efficiency and business performance is not only an important issue for business managers, but also an important reference for investors who are determining their investment strategy. Therefore, this study uses IGRA, the entropy weight method, the DEA and VIKOR methods, and the proposed DEA-IG model and VIKOR-IGE model to conduct efficiency analysis and performance evaluation of Taiwan's 38 listed semiconductor companies in 2010, respectively. The results can serve as reference for management to set strategic and operational goals for companies, and performance evaluation results can provide investors with a reference for investment decision-making.

The results of the DEA-IG model show that two representative output variables (total revenue and net sales) and four representatives input variables (total assets, operating expenses, administrative expenses and inventory) were selected by using globalized IGRA, as the input and output indicators in the DEA model. Based on the results, Taiwan's 38 listed semiconductor companies are divided into two groups of 11 efficient companies and 27 inefficient companies. 
We selected 9 representative financial indicators by using globalized IGRA, with two output indicators as performance evaluation indicators. Then we applied the entropy method to calculate the object weight of each indicator. The results showed that the "total revenue" is the most important indicator influencing a semiconductor company's performance. Finally, according to the above two groups, this study proposed a VIKOR-IGE model for evaluating and ranking each of the two groups. The final ranking results show that companies F6 and F16 are the best choices among the efficient company group, followed by company F10 and F36. And company F35 had the poorest operating performance and was ranked last in the inefficient companies group, suggesting that this company has the highest probability of failure in Taiwan's semiconductor industry.

Investors often choose investment targets based on past performance rankings to select a company, and do not consider the company's operating efficiency. However, the operational efficiency and business performance of a company are inexorably linked. Therefore, when the investors make investment decisions, we recommend that they choose companies with higher efficiency and operating performance as investment targets.

\section{Acknowledgements}

The authors would like to thank the National Science Council of the Republic of China, Taiwan for financially supporting this research under Contract No. NSC 101-2410-H-275-002.

\section{References}

Athawale, V. M.; Kumar, R.; Chakraborty, S. 2011. Decision making for material selection using the UTA method, International Journal of Advanced Manufacturing Technology 57: 1-12. http://dx.doi.org/10.1007/s00170-011-3293-7

Avkiran, N. K. 1999. The evidence on efficiency gains: the role of mergers and the benefits to the public, Journal of Banking \& Finance 23(7): 991-1013. http://dx.doi.org/10.1016/S0378-4266(98)00129-0

Avkiran, N. K. 2001. Investigating technical and scale efficiencies of Australian universities through data envelopment analysis, Socio-Economic Planning Sciences 35(1): 57-80. http://dx.doi.org/10.1016/S0038-0121(00)00010-0

Azimi, R.; Yazdani-Chamzini, A.; Fooladgar, M. M.; Hossein, M. 2011. Evaluating the strategies of the Iranian mining sector using a integrated model, International Journal of Management Science and Engineering Management 6(6): 459-466. http://dx.doi.org/10.1080/17509653.2011.10671196

Bakshi, T.; Sarkar, B. 2011. MCA based performance evaluation of project selection, International Journal of Software Engineering \& Applications 2(2): 14-22. http://dx.doi.org/10.5121/ijsea.2011.2202

Baležentis, A.; Baležentis, T. 2011. Assessing the efficiency of Lithuanian transport sector by applying the methods of MULTIMOORA and data envelopment analysis, Transport 26(3): 263-270. http://dx.doi.org/10.3846/16484142.2011.621146

Banker, R. D.; Charnes, A.; Cooper, W. W. 1984. Some models for estimating technical and scale inefficiencies in data envelopment analysis, Management Science 30(9): 1078-1092.

http://dx.doi.org/10.1287/mnsc.30.9.1078

Bindu Madhuri, C.; Anand Chandulal, J. 2010. Evaluating web sites using COPRAS-GRA combined with grey clustering, International Journal of Engineering Science and Technology 2(10): 5280-5294. Available from Internet: http://www.ijest.info/docs/IJEST10-02-10-046.pdf 
Cao, X.; Yang, F. 2011. Measuring the performance of Internet companies using a two-stage data envelopment analysis model, Enterprise Information Systems 5(2): 207-217. http://dx.doi.org/10.1080/17517575.2010.528039

Cetin, M. K.; Cetin, E. I. 2010. Multi-criteria analysis of banks' performances, International Journal of Economics and Finance Studies 2(2): 73-78. Available from Internet: http://www.sobiad.org/eJOURNALS/journal_IJEF/archieves/2010_2/09m_koray_cetin.pdf

Chang, C. L.; Hsu, C. H. 2009. Multi-criteria analysis via the VIKOR method for prioritizing land-use restraint strategies in the Tseng-Wen reservoir watershed, Journal of Environmental Management 90(11): 3226-3230. http://dx.doi.org/10.1016/j.jenvman.2009.04.020

Chang, C. C.; Hung, S. W.; Huang, S. Y. 2011. Evaluating the operational performance of knowledge-based industries: the perspective of intellectual capital, Quality \& Quantity 47(3): 1367-1383. http://dx.doi.org/10.1007/s11135-011-9595-x

Charnes, A.; Cooper, W. W. 1984. Preface to topics in data envelopment analysis, Annals of Operations Research 2(1): 59-94. http://dx.doi.org/10.1007/BF01874733

Charnes, A.; Cooper, W. W.; Rhodes, E. 1978. Measuring the efficiency of decision making units, European Journal of Operational Research 2(6): 429-444. http://dx.doi.org/10.1016/0377-2217(78)90138-8

Chen, J. K. 2012. The assessment of vision re-creation indices for the automotive industry in Taiwan: a hybrid fuzzy model approach, Measurement 45(5): 909-917. http://dx.doi.org/10.1016/j.measurement.2012.02.004

Chen, C. J.; Wu, H. L.; Lin, B. W. 2006. Evaluating the development of high-tech industries: Taiwan's science park, Technological Forecasting and Social Change 73(4): 452-465. http://dx.doi.org/10.1016/j.techfore.2005.04.003

Chen, T. Y.; Chen, L. 2007. DEA performance evaluation based on BSC indicators incorporated: the case of semiconductor industry, International Journal of Productivity and Performance Management 56(4): 335-357. http://dx.doi.org/10.1108/17410400710745333

Chen, F. L.; Chen, Y. C. 2010. Evaluating the maintenance performance of the semiconductor factories based on the analytical hierarchy process and grey relational analysis, American Journal of Applied Sciences 7(4): 568-574. http://dx.doi.org/10.3844/ajassp.2010.568.574

Chen, I. S.; Chen, J. K. 2010. How to manage knowledge well? Evidence from the life insurance industry, African Journal of Business Management 4(17): 3605-3617. Available from Internet: http://www. academicjournals.org/ajbm/pdf/pdf2010/4Dec/Chen\%20and\%20Chen.pdf

Chen, Y. S.; Chen, B. Y. 2011. Applying DEA, MPI, and grey model to explore the operation performance of the Taiwanese wafer fabrication industry, Technological Forecasting and Social Change 78(3): 536-546. http://dx.doi.org/10.1016/j.techfore.2010.04.013

Chiang, Y. M.; Hsieh, H. H. 2009. The use of the Taguchi method with grey relational analysis to optimize the thin-film sputtering process with multiple quality characteristic in color filter manufacturing, Computers \& Industrial Engineering 56(2): 648-661. http://dx.doi.org/10.1016/j.cie.2007.12.020

Chiu, Y. H.; Huang, C. W. 2011. Evaluating the optimal occupancy rate, operational efficiency, and profitability efficiency of Taiwan's international tourist hotels, Service Industries Journal 31(13): 2145-2162. http://dx.doi.org/10.1080/02642069.2010.503889

Chou, Y. C.; Yen, H. Y.; Sun, C. C. 2012. An integrate method for performance of women in science and technology based on entropy measure for objective weighting, Quality \& Quantity 48(1): 157-172. http://dx.doi.org/10.1007/s11135-012-9756-6

Chu, M. T.; Shyu, J.; Tzeng, G. H.; Khosla, R. 2007. Comparison among three analytical methods for knowledge communities group-decision analysis, Expert Systems with Applications 33(4): 1011-1024. http://dx.doi.org/10.1016/j.eswa.2006.08.026

Coelli, T. 1996. A guide to DEAP version 2.1: a data envelopment analysis (computer) program. Australia: University of New England. 
Coelli, T.; Rao, D. P.; Battese, G. E. 1998. An introduction to efficiency analysis. Boston: Kluwer Academic Publishers. http://dx.doi.org/10.1007/978-1-4615-5493-6

Cooper, W. W.; Seiford, L. M.; Tone, K. 2000. Data envelopment analysis. Boston: Kluwer Academic Publishers.

Cooper, W. W.; Seiford, L. M.; Tone, K. 2006. Introduction to data envelopment analysis and its uses. New York: Springer.

Cummins, J. D.; Weiss, M. A.; Xie, X.; Zi, H. 2010. Economies of scope in financial services: a DEA efficiency analysis of the US insurance industry, Journal of Banking \& Finance 34(7): 1525-1539. http://dx.doi.org/10.1016/j.jbankfin.2010.02.025

Deng, J. L. 1988. Grey colored multi-dimensional programming. Wuhan: Huazhong University of Science and Technology Press.

Diskaya, F.; Emir, S.; Orhan, N. 2011. Measuring the technical efficiency of telecommunication sector within global crisis: comparison of G8 countries and Turkey, Procedia-Social and Behavioral Sciences 24: 206-218. http://dx.doi.org/10.1016/j.sbspro.2011.09.037

Duran, S.; Zehir, C. 2011. Analyzing the technical efficiency on the effects of foreign portfolio investment in the financing of small and medium-sized enterprises (SMEs) in Turkey, African Journal of Business Management 5(21): 8567-8575. Available from Internet: http://www.academicjournals.org/ajbm/ PDF/pdf2011/23Sept/Duran\%20and\%20\%20Zehir.pdf

Eken, M. H.; Kale, S. 2011. Measuring bank branch performance using Data Envelopment Analysis (DEA): the case of Turkish bank branches, African Journal of Business Management 5(3): 889-901. Available from Internet: http://www.academicjournals.org/ajbm/PDF/pdf2011/4Feb/Eken\%20and\%20Kale.pdf

Eling, M.; Luhnen, M. 2010. Efficiency in the international insurance industry: a cross-country comparison, Journal of Banking \& Finance 34(7): 1497-1509. http://dx.doi.org/10.1016/j.jbankfin.2009.08.026

Farrell, M. J. 1957. The measurement of productive efficiency, Journal of the Royal Statistical Society Series A (General) 120(3): 253-290. http://dx.doi.org/10.2307/2343100

Feng, C. M.; Wang, R. T. 2000. Performance evaluation for airlines including the consideration of financial ratios, Journal of Air Transport Management 6(3): 133-142.

http://dx.doi.org/10.1016/S0969-6997(00)00003-X

Fu, H. P.; Chu, K. K.; Chao, P.; Lee, H. H.; Liao, H. C. 2011. Using fuzzy AHP and VIKOR for benchmarking analysis in the hotel industry, Service Industries Journal 31(14): 2373-2389.

http://dx.doi.org/10.1080/02642069.2010.503874

Ginevičius, R.; Krivka, A.; Šimkūnaite, J. 2010. The model of forming competitive strategy of an enterprise under the conditions of oligopolic market, Journal of Business Economics and Management 11(3): 367-395. http://dx.doi.org/10.3846/jbem.2010.18

Golany, B.; Roll, Y. 1989. An application procedure for DEA, Omega 17(3): 237-250. http://dx.doi.org/10.1016/0305-0483(89)90029-7

Guitouni, A.; Martel, J. M. 1998. Tentative guidelines to help choosing an appropriate MCDA method, European Journal of Operational Research 109(2): 501-521. http://dx.doi.org/10.1016/S0377-2217(98)00073-3

Hadi-Vencheh, A.; Mohamadghasemi, A. 2011. A fuzzy AHP-DEA approach for multiple criteria ABC inventory classification, Expert Systems with Applications 38(4): 3346-3352.

http://dx.doi.org/10.1016/j.eswa.2010.08.119

Halkos, G. E.; Tzeremes, N. G. 2012. Industry performance evaluation with the use of financial ratios: an application of bootstrapped DEA, Expert Systems with Applications 39(5): 5872-5880.

http://dx.doi.org/10.1016/j.eswa.2011.11.080

Han, Z.; Liu, P. 2011. A fuzzy multi-attribute decision-making method under risk with unknown attribute weights, Technological and Economic Development of Economy 17(2): 246-258.

http://dx.doi.org/10.3846/20294913.2011.580575 
Haugland, S. A.; Myrtveit, I.; Nygaard, A. 2007. Market orientation and performance in the service industry: a data envelopment analysis, Journal of Business Research 60(11): 1191-1197. http://dx.doi.org/10.1016/j.jbusres.2007.03.005

Ho, C. T. 2006. Measuring bank operations performance: an approach based on grey relation analysis, Journal of the Operational Research Society 57(4): 337-349. http://dx.doi.org/10.1057/palgrave.jors.2601985

Ho, C. T. B.; Liao, C.; Kim, H. 2011. Valuing Internet companies: a DEA-based multiple valuation approach, Journal of the Operational Research Society 62(12): 2097-2106. http://dx.doi.org/10.1057/jors.2010.191

Hsu, L. C. 2014. A hybrid multiple riteria decision-making model for investment decision making, Journal of Business Economics and Management 15(3): 509-529. http://dx.doi.org/10.3846/16111699.2012.722563

Huang, K. Y.; Wan, S. 2011. Application of enhanced cluster validity index function to automatic stock portfolio selection system, Information Technology and Management 12(3): 213-228. http://dx.doi.org/10.1007/s10799-011-0103-8

Hung, S. W.; Liu, M. C. 2010. Exploring the operating efficiency of semiconductor industry by a sustainable development approach, International Journal of Green Economics 4(2): 145-155. http://dx.doi.org/10.1504/IJGE.2010.035336

Hung, S. W.; Lu, W. M. 2008. The comparative productivity efficiency of Taiwan's integrated circuits packaging/testing firms, INFOR: Information Systems and Operational Research 46(3): 189-198. http://dx.doi.org/10.3138/infor.46.3.189

Ishizaka, A.; Nemery, P. 2011. Selecting the best statistical distribution with PROMETHEE and GAIA, Computers \& Industrial Engineering 61(4): 958-969. http://dx.doi.org/10.1016/j.cie.2011.06.008

Kaya, T.; Kahraman, C. 2011. An integrated fuzzy AHP-ELECTRE methodology for environmental impact assessment, Expert Systems with Applications 38(7): 8553-8562. http://dx.doi.org/10.1016/j.eswa.2011.01.057

Kozmetsky, G.; Yue, P. 1998. Comparative performance of global semiconductor companies, Omega 26(2): 153-175. http://dx.doi.org/10.1016/S0305-0483(97)00011-X

Kung, C. Y.; Wen, K. L. 2007. Applying grey relational analysis and grey decision-making to evaluate the relationship between company attributes and its financial performance - a case study of venture capital enterprises in Taiwan, Decision Support Systems 43(3): 842-852. http://dx.doi.org/10.1016/j.dss.2006.12.012

Kuo, M. S.; Liang, G. S. 2011. Combining VIKOR with GRA techniques to evaluate service quality of airports under fuzzy environment, Expert Systems with Applications 38(3): 1304-1312. http://dx.doi.org/10.1016/j.eswa.2010.07.003

Lee, J. H.; Park, S. C. 2005. Intelligent profitable customers segmentation system based on business intelligence tools, Expert Systems with Applications 29(1): 145-152. http://dx.doi.org/10.1016/j.eswa.2005.01.013

Lee, P. T. W.; Lin, C. W.; Shin, S. H. 2012. A comparative study on financial positions of shipping companies in Taiwan and Korea using entropy and grey relation analysis, Expert Systems with Applications 39(5): 5649-5657. http://dx.doi.org/10.1016/j.eswa.2011.11.052

Lee, Z. Y.; Pai, C. C. 2011. Operation analysis and performance assessment for TFT-LCD manufacturers using improved DEA, Expert Systems with Applications 38(4): 4014-4024. http://dx.doi.org/10.1016/j.eswa.2010.09.063

Li, W. 2011. Applying grey relational analysis to evaluate the factors affecting innovation capability: evidence from Chinese high-tech industries, Canadian Social Science 7(3): 119-124. http://dx.doi.org/10.3968/j.css.1923669720110703.019

Lin, P. Y.; Lee, T. R.; Dadura, A. M. 2011. Using grey relational analysis and TRIZ to identify KSFs and strategies for choosing importers and exporters: an example of the Taiwanese hand-tool industry, Journal of Manufacturing Technology Management 22(4): 474-488. http://dx.doi.org/10.1108/17410381111126418 
Liu, F. H. F.; Wang, P. 2008. DEA Malmquist productivity measure: Taiwanese semiconductor companies, International Journal of Production Economics 112(1): 367-379.

http://dx.doi.org/10.1016/j.ijpe.2007.03.015

Liu, P.; Wang, M. 2011. An extended VIKOR method for multiple attribute group decision making based on generalized interval-valued trapezoidal fuzzy numbers, Scientific Research and Essays 6(4): 766-776. Available from Internet: http://academicjournals.org/sre/PDF/pdf2011/18Feb/Liu\%20 and\%20Wang.pdf

Long, J.; Li, Y. X. 2011. Research on excessive investment with DEA analysis for Chinese listed companies, Advanced Materials Research 225: 1208-1211.

http://dx.doi.org/10.4028/www.scientific.net/AMR.225-226.1208

Lotfi, F. H.; Fallahnejad, R.; Navidi, N. 2011. Ranking efficient units in DEA by using TOPSIS method, Applied Mathematical Sciences 5(17): 805-815. Available from Internet: http://m-hikari.com/ams/ ams-2011/ams-17-20-2011/lotfiAMS17-20-2011-1.pdf

Lu, L. Y. Y. 2011. Before and after the millennium: productivity analysis of the supply chain of Taiwan's IC industry, Applied Economics 43(22): 2993-2996. http://dx.doi.org/10.1080/00036840903357348

Lu, S.; Tang, J. 2011. Research on evaluation of auto parts suppliers by VIKOR method based on intuitionistic language multi-criteria, Key Engineering Materials 467: 31-35. http://dx.doi.org/10.4028/www.scientific.net/KEM.467-469.31

Lu, W. M.; Hung, S. W. 2010. Assessing the performance of a vertically disintegrated chain by the DEA approach - a case study of Taiwanese semiconductor firms, International Journal of Production Research 48(4): 1155-1170. http://dx.doi.org/10.1080/00207540802484929

Morita, H.; Avkiran, N. K. 2009. Selecting inputs and outputs in data envelopment analysis by designing statistical experiments, Journal of the Operations Research 52(2): 163-173.

http://dx.doi.org/view/UQ:185244

Nayebi, M. A.; Mosadegh, M. J.; Rad, A. M. 2012. Application of VIKOR-BSC model in development of organizational entrepreneurship, World Applied Sciences Journal 18(8): 1163-1171.

http://dx.doi.org/10.5829/idosi.wasj.2012.18.08.1177

Olson, D. 2004. Comparison of weights in TOPSIS models, Mathematical and Computer Modelling 40(7-8): 721-727. http://dx.doi.org/10.1016/j.mcm.2004.10.003

Opricovic, S. 1998. Multi-criteria optimization of civil engineering systems. Faculty of Civil Engineering, Belgrade.

Opricovic, S.; Tzeng, G. H. 2004. Compromise solution by MCDM methods: a comparative analysis of VIKOR and TOPSIS, European Journal of Operational Research 156(2): 445-455. http://dx.doi.org/10.1016/S0377-2217(03)00020-1

Opricovic, S.; Tzeng, G. H. 2007. Extended VIKOR method in comparison with outranking methods, European Journal of Operational Research 178(2): 514-529. http://dx.doi.org/10.1016/j.ejor.2006.01.020

Pan, W. H.; Feng, Y. Y.; Huang, Y. C.; Chen, Y. K. 2008. Performance review of Taiwanese IC design industry: DEA-based Malmquist productivity measure, WSEAS Transactions on Computers 7(8): 1291-1299. Available from Internet: http://www.wseas.us/e-library/transactions/computers/2008/30-643N.pdf

Podvezko, V. 2011. The comparative analysis of MCDA methods SAW and COPRAS, Engineering Economics 22(2): 134-146. http://dx.doi.org/10.5755/j01.ee.22.2.310

Purjavad, E.; Shirouyehzad, H. 2011. A MCDM approach for prioritizing production lines: a case study, International Journal of Business and Management 6(10): 221-229. http://dx.doi.org/10.5539/ijbm.v6n10p221

Ray, S. C. 2004. Data envelopment analysis: theory and techniques for economics and operations research. Cambridge UK: Cambridge University Press.

Sallehuddin, R.; Shamsuddin, S. M. H. 2009. Hybrid grey relational artificial neural network and auto regressive integrated moving average model for forecasting time-series data, Applied Artificial Intelligence 23(5): 443-486. http://dx.doi.org/10.1080/08839510902879384 
Shannon, C. E. 1948. A mathematical theory of communication, Bell System Technical Journal 27(3): 379-423. http://dx.doi.org/10.1002/j.1538-7305.1948.tb01338.x

Shannon, C. E.; Weaver, W. 1949. The mathematical theory of communication. Urbana: University of Illinois Press.

Shaverdi, M.; Akbari, M.; Tafti, S. F. 2011. Combining fuzzy MCDM with BSC approach in performance evaluation of Iranian private banking sector, Advances in Fuzzy Systems 2011: 1-12. http://dx.doi.org/10.1155/2011/148712

Shemshadi, A.; Shirazi, H.; Toreihi, M.; Tarokh, M. 2011. A fuzzy VIKOR method for supplier selection based on entropy measure for objective weighting, Expert Systems with Applications 38(10): 12160-12167. http://dx.doi.org/10.1016/j.eswa.2011.03.027

Shuai, J. J.; Wu, W. W. 2011. Evaluating the influence of e-marketing on hotel performance by DEA and grey entropy, Expert Systems with Applications 38(7): 8763-8769. http://dx.doi.org/10.1016/j.eswa.2011.01.086

Staub, R. B.; Da Silva E Souza, G.; Tabak, B. M. 2010. Evolution of bank efficiency in Brazil: a DEA approach, European Journal of Operational Research 202(1): 204-213. http://dx.doi.org/10.1016/j.ejor.2009.04.025

Stein, H. D. 2010. Allocation rules with outside option in cooperation games with time-inconsistency, Journal of Business Economics and Management 11(1): 56-96. http://dx.doi.org/10.3846/jbem.2010.04

Sun, C. C. 2011. A hybrid performance evaluation system for notebook computer ODM companies, African Journal of Business Management 5(3): 987-1000. http://dx.doi.org/10.5897/AJBM10.903

Toloie-Eshlaghy, A.; Homayonfar, M. 2011. MCDM methodologies and applications: a literature review from 1999 to 2009, Research Journal of International Studies 21: 86-137. Available from Internet: http://www.eurojournals.com/RJIS_21_09.pdf

Tone, K. 2001. A slacks-based measure of efficiency in data envelopment analysis, European Journal of Operational Research 130(3): 498-509. http://dx.doi.org/10.1016/S0377-2217(99)00407-5

Tone, K.; Tsutsui, M. 2010. An epsilon-based measure of efficiency in DEA - a third pole of technical efficiency, European Journal of Operational Research 207(3): 1554-1563. http://dx.doi.org/10.1016/j.ejor.2010.07.014

Tsai, B. H. 2011. Exploring the influence of enterprise resource planning (ERP) implementation on corporate performance using a modified data envelopment analysis (DEA) approach, African Journal of Business Management 5(14): 5435-5448. Available from Internet: http://www.academicjournals. org/ajbm/PDF/pdf2011/18\%20July/Tsai.pdf

Tsai, W.; Chou, W.; Lai, C. 2010. An effective evaluation model and improvement analysis for national park websites: a case study of Taiwan, Tourism Management 31(6): 936-952.

http://dx.doi.org/10.1016/j.tourman.2010.01.016

Tseng, F. M.; Chiu, Y. J.; Chen, J. S. 2009. Measuring business performance in the high-tech manufacturing industry: a case study of Taiwan's large-sized TFT-LCD panel companies, Omega 37(3): 686-697. http://dx.doi.org/10.1016/j.omega.2007.07.004

Wang, C. N.; Chang, Y. L.; Wu, T. C. 2011. A novel decision approach on selecting alliance partners of supply chain in photovoltaic industry, African Journal of Business Management 5(33): 12702-12710. http://dx.doi.org/10.5897/AJBM10.1274

Wang, Y. J. 2008. Applying FMCDM to evaluate financial performance of domestic airlines in Taiwan, Expert Systems with Applications 34(3): 1837-1845. http://dx.doi.org/10.1016/j.eswa.2007.02.029

Wang, Y. J. 2009. Combining grey relation analysis with FMCGDM to evaluate financial performance of Taiwan container lines, Expert Systems with Applications 36(2): 2424-2432. http://dx.doi.org/10.1016/j.eswa.2007.12.027

Wang, R. T.; Ho, C. T.; Oh, K. B. 2010. Measuring production and marketing efficiency using grey relation analysis and data envelopment analysis, International Journal of Production Research 48(1): 183-199. http://dx.doi.org/10.1080/00207540802446803 
Wang, Y. J.; Lee, H. S. 2010. Evaluating financial performance of Taiwan container shipping companies by strength and weakness indices, International Journal of Computer Mathematics 87(1): 38-52. http://dx.doi.org/10.1080/00405000701489412

Wen, K. L. 2004. Grey systems: modeling and prediction. Yang's Scientific Research Institute, USA.

Wong, C. C.; Lai, H. R. 2000. A new grey relational measurement, Journal of Grey System 12(4): 341-346.

Wu, D. 2009. Performance evaluation: an integrated method using data envelopment analysis and fuzzy preference relations, European Journal of Operational Research 194(1): 227-235. http://dx.doi.org/10.1016/j.ejor.2007.10.009

Wu, M.; Liu, Z. 2011. The supplier selection application based on two methods: VIKOR algorithm with entropy method and fuzzy TOPSIS with vague sets method, International Journal of Management Science and Engineering Management 6(2): 110-116. Available from Internet: http://www.ijmsem. org/upfiles/Download/2011022420420028522.pdf

Wu, M. T.; Liao, P. W.; Cheng, Y. S. 2007. The study of semiconductor industry manager'management competence and training and development in Taiwan, International Conference on Engineering Education 2007, 3-7 September 2007, Coimbra, Portugal. Available from Internet: http://www.ineer.org/ Events/ICEE2007/papers/251.pdf

Yalcin, N.; Bayrakdaroglu, A.; Kahraman, C. 2012. Application of fuzzy multi-criteria decision making methods for financial performance evaluation of Turkish manufacturing industries, Expert Systems with Applications 39(1): 350-364. http://dx.doi.org/10.1016/j.eswa.2011.07.024

Yan, Q.; Wang, X.; He, S.; Zhu, L. 2011. Research on entropy-TOPSIS in external environment evaluation of power grid corporation, Innovative Computing and Information 232: 420-427. http://dx.doi.org/10.1007/978-3-642-23998-4_58

Zavadskas, E. K.; Turskis, Z. 2011. Multiple criteria decision making (MCDM) methods in economics: an overview, Technological and Economic Development of Economy 17(2): 397-427. http://dx.doi.org/10.3846/20294913.2011.593291

Zhu, J. 2003. Quantitative models for performance evaluation and benchmarking. Boston: Kluwer Academic Publishers.

Zolfani, S. H.; Sedaghat, M.; Zavadskas, E. K. 2012. Performance evaluating of rural ICT centers (telecenters), applying fuzzy AHP, SAW-G and TOPSIS Grey, a case study in Iran, Technological and Economic Development of Economy 18(2): 364-387. http://dx.doi.org/10.3846/20294913.2012.685110

Zou, X.; Huan, T. C. 2011. A study of the intellectual capital's impact on listed banks' performance in China, African Journal of Business Management 5(12): 5001-5009. Available from Internet: http://www. academicjournals.org/ajbm/PDF/pdf2011/18June/Zou\%20and\%20Huan.pdf

Li-Chang HSU is a Professor of Economics at Ling Tung University, Taiwan. His articles are published by British Journal of Management, Journal of Business Economics and Management, Service Business, Journal of Electronic Commerce Research, Technological Forecasting and Social Change, Expert Systems with Application, and others. His research interests include decision making theory, grey system theory, technology management and strategy management. 